УДК 658.012.32

DOI: $10.15587 / 2313-8416.2015 .36106$

\title{
АНАЛИЗ, ИССЛЕДОВАНИЕ И РАЗВИТИЕ КОНКУРЕНТОСПОСОБНОСТИ МИНИ-ГОСТИНИЦ г. КИЕВА
}

\author{
(C) В. М. Левыкин, В. В. Дэвон
}

В статье рассмотрены качественные характеристики конкурентного преимущества мини-гостиниц (КПМ) г. Киева, перспектива сохранения и развития конкурентоспособных позиций на рынке гостеприимства (РГ) Украины. Дан анализ РГ и туристического рынка Украины, действующего украинского законодательства (УЗ). Систематизированы научные подходы к определению понятия «качество гостиничных услуг» (КГУ). Проведено анкетирование в 70 мини-гостиницах (м-г)

Ключевые слова: качество услуг, конкурентное преимущество, мини-гостинищь, классификащия гостиниц, категория гостинии, проект

This study deals with Kiev mini-hotels competitive advantage (MCA) quality characteristics, overview of competitive positions on the Ukrainian hospitality market (HM) savings and development. The HM and Ukrainian tourist market have been analyzed, as well as the current Ukrainian Law (UL). Scientific approaches have been systemized for determination of the "hotel services quality" (HSQ) concept. Questionnaires have been held in 70 mini-hotels Keywords: service quality, competitive advantage, mini-hotels, hotels classification, hotels category, project

\section{1. Введение}

РГ - одна из главнейших ниш индустрии туризма. М-г играют ключевую роль в стратегическом позиционировании туризма г. Киева. Каждая туристическая (тур.) поездка связана с обеспечением туристов мест для временного проживания, в независимости от уровня организуемого отдыха. Сегодня ММ должны принимать во внимание желание клиентов, считаться с их требованиями, внимательно относиться к просьбам и предложениям клиентов, обращать внимание на вкусы своих посетителей, их привычки, национальные (нац.) тонкости, учитывать их хобби и интересы при организации досуга. Начало 2015 г., несмотря на неоднозначное политическое (пол.) положение в Украине, девальвацию нац. валюты и общий экономический (эк.) спад, тем не менее, характеризуется положительной динамикой увеличения количества м-г и развитием ниши малого гостиничного бизнеса (ГБ). Эта тенденция - рефлекторность общемировых закономерностей на РГ. Очевидно, что постоянные волнения и ежедневные изменения в сфере деятельности м-г, поддерживаемые социальными (соц.), эк., пол., рыночными, и другими (др.) изменениями, делают необходимым возведение их КП на более высокий уровень как на уровне тур. направления, так и на уровне управления субъектов. Инновации в области КГУ м-г и маркетинга м-Г - главнейшие факторы, влияющие на увеличение конкурентоспособности м-г (КМ) и усиливающие их позиции на РГ. Сегодня ММ лучше придерживаться стратегии спокойствия и стабильности, улучшать свой сервис и быть доброжелательными и открытыми по отношению к клиентам. Кризисные времена закончатся и м-г, достойно с ними справившиеся, заслужат уважительное и доверительное отношение к себе. М-г играют ключевую роль в стратегическом позиционировании туризма г. Киева.

В статье проводится детальный анализ управления проектов м-г (УПМ) с точки зрения КГУ в контексте новой пол. и эк. обстановки, особенно это касается установления требований в условиях открытости управления и КМ. Задача менеджеров м-г (MM) - ус- пешно руководить изменениями и построение взаимоотношений, дающих возможность маркетинговых перерывов в условиях более требовательных рынков. В статье основное внимание будет уделяться КГУ - как основы КМ. В битве за лидирующие позиции на РГ, желая быть успешными и конкурентоспособными ММ г. Киева не прекращают нахождение новых, действенных способов развития и становления. Как показывает практика, самым надежным и выигрышным способом организационного развития на украинском (укр.) РГ (УРГ) сегодня есть повышение КГУ, играющее ключевую роль в УПМ. Очень важно грамотно построить и результативно реализовать в м-г систему КГУ, как надежного и сильного инструмента увеличения эффективности деятельности м-г, влияющего на рост КМ, снижение себестоимости и возможности понижения цен на оказываемые гостиничные услуги (ГУ), что, в свою очередь, благотворно скажется на укрупнении прибылей м-г. Правильное конструирование и непрерывное улучшение КГУ - главнейшее КПМ, благодаря которому она приобретает успех и завоевывает репутацию, занимает выгодные ниши на рынке, укрупняя свои масштабы и развивая свои мощности, что непременно скажется на повышении благосостояния не только ММ, но и персонала, функционирование и развитие, что обеспечит уверенность в будущем, стабильность и процветание. Оказывая уникальные высококлассные ГУ, пользующиеся повышенным спросом у укр. и иностранных туристов (ИТ), м-г приносит пользу обществу и экономике страны, показывает соц. ответственность малого бизнеса. Следовательно, организованная в м-г на высшем уровне система КГУ несет благую соц. функцию как для своих сотрудников и клиентов, так и для государственного (гос.) сектора экономики страны. Поэтому сегодня так актуальна проблема разработки организационных (орг.) изменений управления КГУ. КГУ - основа увеличения конкурентоспособности м-г (УКМ). Качество м-г включает «наилучшие возможные» ГУ, превышающие ожидания клиентов. Такой подход к КГУ - важнейший фактор для достижения КПМ. С каждым годом поток ИТ в 
Украине возрастает. За последний год Украина показывает серьезный подъем во всех мировых рейтингах как тур. страна. Несмотря на нестабильное пол. положение, популярность приобретена благодаря нескольким мероприятиям международного (межд). характера, проходившим и планирующимся к проведению в Украине. Это песенный конкурс "Евровидение", футбольный чемпионат Евро-2012. На протяжении ближайших лет Украине удастся окончательно преодолеть скептицизм и опасения ИТ. В 2015-2016 гг. количество ИТ, въезжающих в Украину, увеличится в 2-3 раза, чему поспособствует и серьезный отток ИТ из России. Снижение тур. потока из Евросоюза и США в Россию составило от $40 \%$ до $60 \%$. Так, поток из Испании сократился на $90 \%$, из Италии - на 60 \%, из Германии - на $40 \%$. По мнению участников РГ, это связано с войной в Украине, в декабре 2014 г. въездной турпоток сократился еще на $60 \%$. Владельцы отелей констатируют, что в 2014 г. загрузка гостиниц в Москве упала на $4 \%$, до $59 \%$, в Санкт-Петербурге - на $3 \%$, до $53 \%$. Украина должна реализовать свой тур. потенциал, при обеспечении ИТ безопасными КГУ и не последнюю роль здесь сыграют м-г, пользующиеся спросом у ИТ. Актуальность этого факта заключается в способности ММ, быстро адаптироваться к изменчивым укр. реалиям, приспособиться к ежечасно меняющимся условиям РГ, оставить весомый вклад в региональное развитие, не боятся технических (тех.) и орг. нововедений, инноваций, совершенствования. В развитии сферы ГУ малый бизнес играет весомое значение - это индикатор оценки уровня развития экономики Украины, база стабильного развития Украины и УК укр. экономики.

Основное внимание в статье уделяется изучению корреляции достижения КПМ с позиций повышения КГУ путем увеличения категории на 1 *.

\section{2. Анализ УЗ, литературных источников и} постановка проблемы

Ниша ГУ на РГ - это активно развивающийся сектор экономики Украины. М-г сегодня имеют великолепный шанс не только стать частью УРГ но и увеличить свое влияние в ГБ. Необходимо правильно проанализировать рыночную (рын.) ситуацию, т.к. от этого будет зависеть в будущем состав игроков на УРГ. В Киеве наблюдается тенденция заполнения рын. ниш иностранными (ин.) гостиничными операторами (ГО). На сегодня в Украине функционирует единственный национальный ГО - Premier-Hotels, в его составе 6 гостиниц. Это объединение абсолютно различных по концепции и набору ГУ гостиниц в крупных деловых и тур. центрах Украины. Благодаря особенностям каждой отдельно взятой гостиницы, сеть гостиниц не занимается вопросами, касающимися унифицированности гостиничного продукта (ГП), кроме этого, это дает возможность удвоить конкурентное преимущество (КП), связанное с позиционированием на РГ и узнаваемостью бренда. Все гостиницы применяют единую систему бронирования. Хотя, трудно определить Premier-Hotels полноценным ГО, т. к. гостиницы этой сети представлены в разных сегментах и под разными торговыми марками. Появление такого ГО объясняется постепенным насыщением РГ гостиниц высшего класса и приходом влиятельных зарубежных ГО, что создало условия, в которых отдельные организации вынуждены кооперировать и придерживаться единой бизнес-стратегии. Тем не менее, эволюция - закономерный вариант развития, - расширение влияния на РГ уже функционирующей организации. Так, выход на рынки Киева и Ялты ГО, в активе которого уже находиться 5* донецкая гостиница «Донбасс-Палас» - яркий пример тенденций роста и расширения укр. компаний на рынке ГУ (РГУ). В истории укр. ГБ гостиница «Донбасс Палас» первой вошла в ассоциацию Тhe Leading Hotels of the World. В ноябре 2005 г. гостиница победила в престижнейшем конкурсе тур. бизнеса World Travel Awards - и была названа Ведущим отелем Украины, а в 2006 г. была признана Ведущим Отелем Украины и Ведущим Бизнес Отелем. Оператор занимается строительством 5* гостиниц в крупных центрах Ураины и зарубежом под брендом «ДП». Что касается гостиниц класса «де-люкс», он задает и определяет высокую динамику и уровень РГ. Спрос на услуги экстра-класса ежегодно растет благодаря перераспределению капитала в Украине и резкого увеличения потока ИТ. ГО может выбрать реализацию строительных проектов или приобретать уже существующие гостиницы с дальнейшей реконструкцией. В усовиях укр. реалий более приемлемой и работающей является стратегия укрупнения на РГУ уровня 1-3*, т. к. эта ниша не наполнена, а имеющиеся мини-гостиницы $1-3 *$ с низким уровнем обслуживания и небольшим набором ГУ. Целевой сегмент мини-гостиниц - укр. туристы (отдыхающие и бизнес-туристы). Из-за отсутствия или невысокой КМ не обращают внимания на ПП в высоком уровне ГУ. Создание единой сети гостиниц с универсальным, единым набором ГУ и высоким КГУ посредством покупки и реконструкции существующего гостиничного фонда малой и средней категорий даст гостинице статус нац. ГО и преимущества доминирования на РГ. Сегодня в этом секторе активность укр. компаний низка, а это может привести к наполнению РГ ин. ГО. Выгоднейшим и прибыльным остается РГ экстракласса и он приближается к насыщению, поэтому очень скоро большинство ГО займутся рынком средних и малых гостиниц с умеренным набором ГУ. Освоение регионов - станет главной целью укр. ГО. Киевский РГ перенасыщен в секторе гостиниц 4-5*, сегодня в Киеве строятся около 10 гостиниц класса люкс и выход на РГ будет возможен лишь путем слияний и поглощений. Ниша гостиниц среднего класса также наполняется, т.к. ММ проявляют активность и приводят состав предоставляемых ГУ и уровень обслуживания в соответствие с европейскими стандартами. Ненасыщенными остаются рынки регионов, где другие показатели спроса. Гостиницы класса люкс пользуются спросом в крупных городах и курортных центрах, а в регионах - м-г и отели среднего уровня, что продиктовано дифференциацией доходов в маленьких городах. Сегодня, приспосабливаясь к новым правилам игры на РГ, ММ призванные обеспечивать КГУ, занимаются их развитием. Чтобы добиться максимальной эффективности ММ необходимо базировать УПМ на стратегическом видении и предвидении, на базе которого строить политику гостиницы, представляющую общие цели и нормы отношений, обеспечивающие жизнеспособность и развитие структуры. MМ должен обеспечить четкую орг. 
структуру, а работа в ней должна быть разделена между всем персоналом на основе профессионализма, с привлечением сторонних специалистов для эффективного преобразования ключевых функций работников, определения их подотчетности, разработки стратегии развития сетей.

Сложным остается взаимодействие с контролирующими гос. органами (КГО): процесс регистрации мг, отвод земельного участка под строительство, прохождение обязательных процедур в ведомствах пожарной охраны и санэпидемиологического контроля, получение необходимых разрешений и сертификатов и т. д. Стандартизация ГУ также проблематична из-за несоответствия укр. и европейской систем стандартизации, что усложняет и замедляет деятельность гостиницы, хотя здесь нац. ГО может реализовать преимущество осведомленности о подобных вопросах и знания тонкостей и “подводных камней” УЗ. Систематизация средств размещения (СР) в Украине производится согласно таким нормативно-правовым документам: «Правила пользования гостиницами и аналогичными СР и предоставления ГУ» (2004 г.), «Порядок предоставления услуг по временному размещению (проживанию)» (2006 г.), «Правила обязательной сертификации (OC) услуг по временному размещению (проживанию)» (Правила) (2007 г.) и на основании 3 нац. стандартов - ДСТУ 4268:2003 «Услуги туристические. СР. Общие требования», ДСТУ 4269:2003 «Услуги туристические. Классификация гостиниц», ДСТУ 4527:2006 «Услуги туристические. СР. Термины и определения».

Правила ОС ГУ по временному размещению, действовавшие для гостиниц с 07.05.1999 г., закрепляли необходимость проведения ОС ГУ относительно безопасности для жизни и здоровья людей, защиты их имущества и охраны окружающей среды и предусматривали процедуру оценки соответствия гостиниц требованиям определенной категории. С 01.10.1999 г. ГУ в Украине подлежат ОС на безопасность, которая проводится по соответствующим правилам в гос. системе УкрСЕПРО с целью установления соответствия ГУ обязательным требованиям нормативных документов Украины. Объекты ОС - это ГУ, оказываемые в коллективных и индивидуальных СР, к которым относятся м-г. Приказ Министерства экономического развития и торговли Украины, вступивший в силу с 08.10.2012 г., исключил из перечня продукции, которая подлежит OC, ГУ и услуги питания, предоставляемые гостиницами, и ввел добровольную сертификацию (ДС) ГУ и оценку соответствия гостиниц требованиям определенной категории на основе договора между органом по сертификации и владельцем. Присвоение «звезд» гостиницам стало возможным по результатам ДС и была отменена сертификация ГУ относительно безопасности для жизни и здоровья людей, а это решающее требование для работы гостиниц. Принимая во внимание то, что ИТ осторожно относятся к турам на Украину, этот факт мог сыграть негативную роль в развитии укр. туризма. Аннулирование единой системы сертификации без внедрения новой системы является нелогичным, более правильной была бы разработка нового, современного механизма контроля, нивелирующего возможные риски. Европейские государства, отказавшиеся от OC, приняли единые стандарты классификации гости- ниц HOTREC, утвержденные Европейской гостиничноресторанной конфедерацией. Для УКМ, европейские гостиницы повсеместно принялись применять новые стандарты для подтверждения своей категории. В сложившихся новых условиях, пользуясь пробелами в УЗ, укр. м-г начали сами присваивать себе нужное им количество звезд, без дополнительных хлопот и лишних затрат, что привело к утрате большинства клиентов, убытки понесли и туроператоры, поселившие своих гостей в отеле с неофициальными «звездочками». Это замедлило рост ГБ, повлияло на упадок тур. рейтинга Украины. ГКО стали говорить о необходимости обязательной категоризации гостиниц (КГ) как о важном шаге на пути к упорядочиванию РГУ. Требовалось менять устоявшиеся критерии классификации гостиниц и приводить их в соответствие с европейскими стандартами и в 2003 г. Министерство курортов и туризма автономной республики Крым (АРК) приняло «Положение о малых гостиницах, мотелях, пансионатах», вводившее понятие данных форм предприятий с ограничением их вместительности от 5 номеров до 100 мест [1]. Неурегулированность этого нормативно-правового акта с общегос. УЗ заключалась в том, что для средств размещения в то время действовал межгос. ГОСТ 28681.4-95 «Туристско-экскурсионное обслуживание. Классификация гостиниц», примененный в Украине в качестве национального стандарта (НС), согласно которому количество номеров в средстве размещения для отнесения его к типу «гостиницы» должно было быть на уровне 10 (ДСТУ 4269:2003). ДС ГУ в Системе УкрСЕПРО производится на соответствие требованиям, которые не отнесены нормативными документами к категории обязательных, в связи с чем КГ по «звездам» (от 1 до 5) реализуется исключительно по желанию заявителя, но на основании требований НС ДСТУ 4269:2003 «Услуги тур. Классификация гостиниц». При этом сертификация на соответствие всем обязательным требованиям нормативных документов должна выполняться в любом случае [2]. Новый порядок КГ был разработан гос. агенством Украины по туризму и курортам. Улучшенная система направлена на обеспечение более простой и прозрачной процедуры КГ, что должно УК не только укр. гостиниц, но и нац. ГП в целом. По состоянию на 15.03.2013 г. из более чем 3,7 тыс. укр. гостиницы лишь чуть более 200 имели официальную категорию. Суть бальной системы заключается в том, что если у гостиницы отсутствуют какие-либо условия, либо ГУ, она сможет компенсировать их другими ГУ. При этом КГ в любом случае должна оставаться добровольной. До 09.11.2013 г. для гостиниц не было обязательным соответствие требованиям, предусмотренным в ДСТУ 4269 «Услуги тур. Классификация гостиниц» в связи с законодательно установленной ДС. 09.11.2013 г. вступил в силу Закон Украины (ЗУ) «Об особенностях осуществления инвестиционной деятельности на территории АРК», ввевший процедуру обязательной КГ. Заключительные положения $3 У$ вносят изменения в $3 У$ «О туризме» и становятся краеугольным камнем для РГУ, регулируя деятельность всех укр. гостиниц, устанавливает для них новые требования. Есть несоответствие УЗ - сертификация гостиниц по-прежнему остается добровольной, т. е. обязательная КГ осуществляется по результатам 
ДС. Порядок проведения ОС включает 7 основных этапов, а СР имеет право сертифицировать ГУ на определенную категорию. Для проверки соблюдения гостиницей требований к определенному разряду комиссия должна сделать оценку качества фактического состояния отдельных элементов гостиницы на основании выборочного обследования номерного фонда (не менее чем $30 \%$ номеров из каждой ценовой категории) и др. помещений и сделать заключение о присвоении определенного количества «звезд» или «уровней». Существуют риски, возможные при работе м-г, с одновременным прохождением предусмотренной УЗ процедуры КГ. В соответствии со ст. 91 Гражданского Кодекса Украины (ГКУ), юридическое (юр.) лицо может осуществлять отдельные виды деятельности, перечень которых устанавливается 3У, после получения им специального разрешения (СР) (лицензии). Согласно ст. 227 ГКУ, возможность признания судом недействительной сделки юр. лица, совершенного им без лицензии. В УЗ нет единого понятия “СР", поэтому однозначно утверждать, что свидетельство и есть СР нет оснований. Поскольку согласно ч. 1 ст. 19 ЗУ о туризме, целью присвоения объектам тур. инфраструктуры категории качества и уровня обслуживания есть повышение КГУ, содействие потребителям в сознательном выборе ГУ, обеспечение равных возможностей субъектам гостиничной деятельности на рынке ГУ, обеспечение защиты прав и законных интересов, жизни, здоровья и имущества граждан, повышение уровня экологической безопасности. Присвоение свидетельству статуса СР может быть установлено судебной практикой. В таком случае налоговые органы, пользуясь правом на фактическую проверку (п. 75.1.3. ст.75 Налогового Кодекса Украины (НКУ)), могут начать повсеместно проверять наличие свидетельств. Далее, путем подачи исков налоговыми органами договора, заключенные гостиницами, не имеющими свидетельств, будут признаны недействительными с соответствующей корректировкой налоговых расходов и доходов (п.140.2 ст.140 НКУ), налогового кредита и налогового обязательства по НДС (ст.197 НКУ). Возможно налоговые органы попытаются привлечь должностных лиц гостиницы к административной ответственности, предусмотренной статьей 164 Кодекса Украины об административных правонарушениях (КоАП) за осуществление хозяйственной деятельности без получения разрешения, иного документа разрешительного характера, если его получение предусмотрено ЗУ. Не стоит исключать и попытки налоговиков обратиться в суд о взыскании в доход государства дохода от ГУ, предоставленных без присвоения гостинице категории, в связи с тем, что такая сделка заключена с несоблюдением «требования о соответствии сделки интересам государства и общества, его моральным принципам» и была заключена «с целью, заведомо противоречащей интересам государства и общества» согласно ч. 3 ст. 228 ГКУ.

Создание и функционирование м-г имеет ряд существенных преимуществ перед более крупными гостиницами. Так, реализация проектов м-г при скромных инвестициях приносит значительные прибыли. Новые м-г уже в первые годы работы имеют более высокий коэффициент загрузки номерного фонда, а их рентабельность около 18 \%, в то время как аналогич- ный показатель для больших отелей находится на уровне 8 - $10 \%$. Срок окупаемости м-г 3-5 лет, у больших гостиниц 7 лет. Одна из причин, по которой м-г открываются и успешно функционируют, это возможность обустройства м-г в «старом» фонде, благодаря чему нет надобности строить новое здание, что очень важно при дефиците мест под застройку и нехватке средств. Основная специфическая отличительная черта м-г от крупных гостинц - персонификация обслуживания. Небольшое количество номеров дает возможность уделять внимание каждому гостю индивидуально. Есть чувство тепла и атмосферы домашнего уюта, всех клиентов знают и помнят в лицо, любые требования, пожелания и просьбы выполняются. VIP персоны предпочитают селиться в малых гостиницах [3]. Однако, несмотря на все преимущества создания м-г, в Украине существует ряд препятствий, которые тормозят развитие данного процесса. Прежде всего - это отсутствие законодательной базы в области средств размещения малых форм, из-за чего наблюдается ограничение роста м-г, возникает проблема их взаимоотношений с КГО, отсутствует система категоризации м-г, не обладающих минимально допустимым номерным фондом. Отсутствие системы обучения и повышения квалификации кадров в области УПМ - еще один неготивный факт. Несовершенство нормативно-правовой базы приводит к тому, что многие малоформатные гостиницы, обязанные проходить процедуру сертификации ГУ размещения, не способны это сделать из-за не соответствия нормам и правилам, установленным в НС исключительно для средних и крупных средств размещения, что приводит к потере большей доли поступлений в бюджет, а м-г не имеют возможности нормально функционировать. В Украине нет и недорогой эффективной системы автоматизированного управления; нет возможности подключения м-г к системе online бронирования. Невнимание со стороны КГО, ответственных за развитие тур. бизнеса в Украине, осложнило развитие м-г, получивших большое распространение во всем мире. Хотя гос. методы и не стимулируют развитие ГБ в Украине, тем не менее ММ самостоятельно привлекают ИТ в Украину, предоставляя качественные ГУ и, соблюдая правила игры, установленные государством, своевременно наполняя бюджет.

Выводы:

- налоговые органы не имеют права проверять наличие свидетельства, т. к. оно не является ни лицензией, ни торговым патентом, ни СР в понимании действующего ЗУ;

- исчерпывающий перечень 3У, предусматривающих необходимость получения $\mathrm{CP}$, др. документа разрешительного характера (ДРХ) установлен в ЗУ «О перечне ДРХ в сфере хозяйственной деятельности». ЗУ «О туризме», ЗУ «Об особенностях осуществления инвестиционной деятельности на территории АРК» отсутствуют в вышеуказанном перечне.

Таким образом, ММ за отсутствие свидетельства не могут быть привлечены к административной ответственности, предусмотренной ст. 164 КоАП.; ЗУ о туризме не устанавливает каких-либо последствий выявления ГУ при отсутствии ее сертификации. Если налоговые органы обратятся в суд о признании недействительным договора о предоставлении ГУ, им придется 
доказать, что такая сделка заключена с несоблюдением «требования о соответствии сделки интересам государства и общества, его моральным принципам» и она была заключена «с целью, заведомо противоречащей интересам государства и общества». В зависимости от приведенных доказательств, ММ и предстоит формировать свои возражения [4].

В секторе ГУ среднего класса появление нац. ГО (НГО) наиболее вероятно, т. к. этот сегмент ненасыщен и перспективен. Скорее всего, гостиничные объекты будут располагаться в регионах и обьеденены единой концепцией. Развитие НГО - это переход на принципиально новый уровень в рамках участия на мировом рынке ГУ - если раньше Украина представляла собой только новые емкие рынки, то создание национальной сети может обозначить нового равноправного игрока.

Качество ГП или ГУ - это восприятие потребителем степени соответствия ГП или ГУ его ожиданиям. Цель области управления качеством проекта (КП) гарантировать, что проект удовлетворяет целям, ради которых был предпринят (соответствие требованиям). КП включает все деятельности проекта, обеспечивающие соответствие проекта целям, ради которых он предпринят. Поэтому управление КП применимо как к проекту, так и к его продукту. КП критически важно, поскольку озвучивает и фиксирует цели, делает их задокументированными. В условиях рынка и конкуренции развитые страны мира воспринимают высокое КП как стратегический коммерческий императив и самый значимый источник нац. богатства. КП во многом определяет престиж государства, является важнейшей составляющей конкурентоспособности. Только на его основе м-г может выжить в условиях конкуренции и получать необходимую прибыль, поэтому деятельность по повышению и обеспечению КГУ в условиях рыночных отношений должна быть приоритетной [5]. Обеспечение качественного обслуживания туристов на РГ однин из важнейших факторов УК. В рын. экономике, проблема КГУ - наиболее важный фактор в улучшении уровня жизни, эк., соц. и экологической безопасности. УКМ, предоставляющих ГУ для укр. и ИТ, способствует тот факт, что одним из самых важных факторов является уровень конкурентоспособности КГУ. В связи с этим проблема оценки КГУ потребителей приобретает особую важность. В январе 1990 г. гостиница Hampton Inns стала рекламировать гарантию КГУ. Клиенту, не удовлетворенному уровнем КГУ, предлагалось вообще не платить за проживание. Большинство менеджеров возражали против такого рода гарантий, предполагая, что придется сдавать номера и нечестным клиентам, которые могут утверждать, что не удовлетворены обслуживанием только для того, чтобы не платить денег. Мнения менеджеров гостиницы разошлись. Но компания верила в честность своих постояльцев и в способности персонала организовать обслуживание на самом высоком уровне. Благодаря такому доверию к гостям и служащим компания завоевала преимущество в конкурентной борьбе на РГ. Изучение мнения клиентуры гостиниц Hampton Inns показало, что больше 85 \% гостей сочли гарантии КГУ в гостинице привлекательными, а 99 \% гостей, воспользовавшихся такой гарантией, сказали, что они вернутся в эту гостиницу, чтобы дать ей еще один шанс. Последующий опыт показал, что почти 40 \% из них вернулись в гостиницу Hampton Inns очень скоро. Однако если руководство понимает, что гость пользуется такой гарантией в свою пользу без достаточных на то оснований, то его имя заносится в банк данных гостиницы Hampton Inns. Когда такие гости в дальнейшем звонят, чтобы заказать номер, то оператор отвечает им, что они были бы рады принять заказ, но гарантии им теперь предоставлены не будут. Таким образом, малое число таких постояльцев сможет воспользоваться этой системой, и то всего 1-2 раза, а затем она на них уже не будет распространяться. Гостиница Hampton Inns подсчитала цену своих гарантий. Оказалось, что из-за гарантий в 1990 г. в гостинице останавливалось 2 \% таких гостей (т. е. 157000 номеров в сутки). Эти гости дали доход в 7 млн. долл., а постояльцы, которые, однажды воспользовавшись гарантией, еще раз вернулись в гостиницу, добавили еще 1 млн. За год Hampton Inns выплатила 350 тыс. долл. клиентам, которые воспользовались гарантией, будучи неудовлетворенными качеством обслуживания. В 1991 г. Hampton Inns от клиентов, привлеченных объявленной гарантией, получила 18 млн. долл., в то время как уровень расходов в связи с выплатами по гарантии оставался постоянным. Одна из причин успеха системы гарантий КГУ Hampton Inns состоит в том, что компания регулярно проводит контроль КГУ. В гостинице понимают, что гарантии могут привести к финансовому краху компании, если не предоставлять гостям удовлетворяющих их ГУ. Поэтому предусмотрены проверки действий служащих в случаях, когда гости прибегают к использованию гарантий. А служащие наблюдают, как гостиница решает проблему гостя, чтобы быть уверенными в том, что все в порядке и тот остался доволен. Система гарантий влияет также и на персонал гостиницы. Когда у служащих спрашивают мнение об их работе, то почти 50 \% отвечают, что система гарантий высокого уровня обслуживания усложняет их деятельность, но дает им уверенность в возможности урегулировать проблемы клиентов собственными силами, не дожидаясь одобрения менеджера. Руководство утверждает, что система гарантий делает гостиницу Hampton Inns лучшим местом работы и укрепляет трудовую мораль сотрудников. Гарантия высокого уровня обслуживания - пример того, какое большое внимание компании на РГ уделяют вопросам повышения КГУ. И совершенно очевидно, что персонал предпочитает работать в компании, которая помогает им оказывать качественные ГУ, удовлетворяющие их клиентов. Исследование показало, что на каждую недобросовестную жалобу приходится 19 справедливых. Опасность при предоставлении гарантий КГУ состоит в том, когда гарантия предлагается, а организация не имеет возможности предложить клиентам удовлетворяющий их уровень КГУ [6]. Изучение 50 крупнейших фирм США компанией Price Waterhouse показало, что качество товаров и обслуживание потребителей для этих фирм было высшим приоритетом. КГУ - важная область деятельности гостиниц. В конце 1980-х гг. резко увеличилось количество публикаций о КГУ. В 1992 г. гостиница Ritz-Carlton первой была награждена Нац. призом качества Malcolm Baldrige, учрежденным Конгрессом США в 1987 г. и присуждаемым ежегодно 
компаниям, достигшим наивысших результатов в реализации программ повышения КГУ. Успех Ritz- Carlton's в борьбе за приз Baldrige ускорил возрастание интереса фирм ГБ к КГУ. Филип Кросби заявляет в Quality is Free, что КП - это соответствие спецификациям, это действие, контролируемое фирмой. Другие исследователи возражают, утверждая, что КП определяют потребители. Эти исследователи определяют КП как способность удовлетворить или превысить ожида- ния клиента. Некоторые исследователи рассматривают улучшение КГУ как переход от стандартных 2* м-г к 4* м-г.

Определим теперь понятие КГУ, рассмотрим его модели, найдем связь между КП и маркетингом, объясним, почему КГУ важно, и рассмотрим, как м-Г могут улучшить КГУ. КГУ резко отличается от КП на производственных фирмах (ПФ). Продукт компании, занятой на РГ, производится и потребляется одновременно, в то время как производство и потребление продуктов ПФ разделено во времени и пространстве. Это дает ПФ время, проверить и снять дефектные изделия, прежде чем потребители получат их. Дефектные изделия стоят фирме денег, но не так много, как клиент, отказывающийся купить это изделие или возвративший его. В компаниях РГ в периоды повышенного спроса на ГУ сложно обеспечить контроль КП. Т. о., достижение КГУ в сфере обслуживания - важная задача, решение которой обеспечивает успех. Деятельность на РГ предполагает высокую степень контакта и координации между служащими и гостями. Стремление к качеству - бесконечный процесс, но сегодня то время, когда им должны заниматься все компании на РГ. Через всеобъемлющие программы КГУ ММ стремятся избежать неудач и повысить восприятие клиентами КГУ. Компании, не способные обеспечить высокое качество ГП и ГУ, могут нести серьезные издержки, по ряду причин:

Во-первых, качество - это свойства и характерные особенности товара, которые вызывают удовлетворение потребителя (УП), отсутствие недостатков, усиливающее чувство УП. Первый тип качества - особенности и свойства ГП - увеличивает его издержки. Потребители должны быть согласны оплатить повышенные затраты на дополнительные особенности и свойства товара или эти особенности должны делать потребителей более лояльными и расположенными к его приобретению. Вовторых, качество бывает техническое (ТК) и функциональное (ФК). ТК - это то, с чем остался клиент после взаимодействия со служащим. Например, ТК - это номера в м-г блюда в ресторане, автомобиль от агентства по аренде автомобилей. ФК - это процесс предоставления товара или ГУ. В течение этого процесса потребители проходят много этапов в их взаимодействии $\mathrm{c}$ персоналом м-г. Например, клиент резервирует номер, получает приветствие от дежурного у двери, сопровождается посыльным к столу регистрации, производит регистрацию у клерка по регистрации и сопровождается в свой номер. Опыт заезда в м-г - это пример ФК. Превосходное ФК может улучшить впечатление от номера, не вполне оправдывающего ожидания клиента, но если ФК плохое, то даже лучший номер не сможет исправить возникшее у клиента чувство неудовлетворенности. На рис. 1 приводится модель КГУ, использующая ТК и ФК как зависимые величины от полного качества.

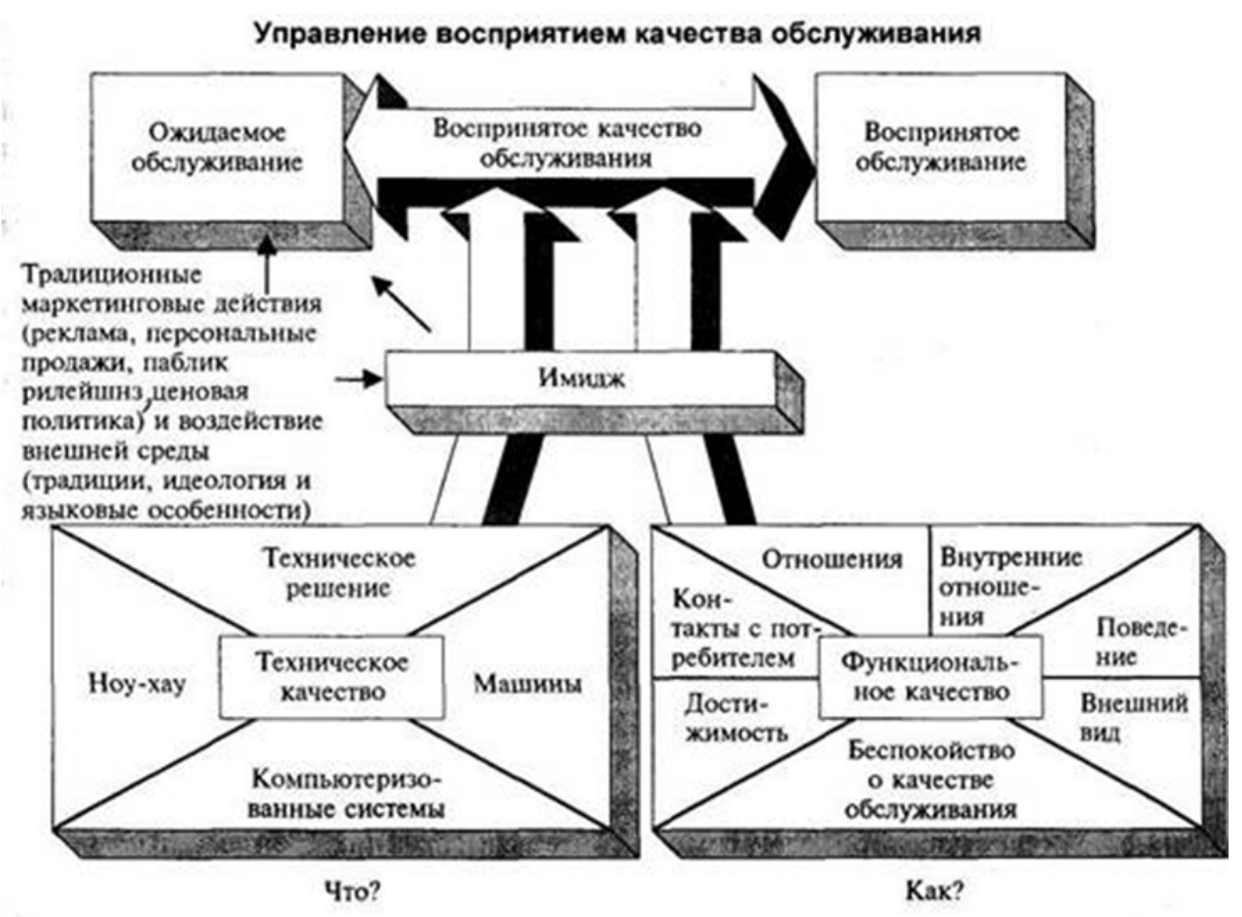

Рис. 1. Управление восприятием качества обслуживания [6]

Еще один тип качества - социальное (этическое) качество (СК). Это качество убеждения, которое не может быть оценено потребителем перед покупкой, и часто его невозможно оценить и после приобретения
ГП или ГУ. Общий имидж м-г воздействует на восприятие клиентами КГУ. Клиенты м-г, с хорошим имиджем, могут не обратить внимания на незначительные огрехи, посчитав их нетипичными. Предоставленное 
КГУ выше у м-г с хорошим имиджем и, наоборот, ниже у м-г с плохим имиджем. СК связывает разработку безопасного товара и предоставление его потребителям и обществу. М-г несет ответственность перед обществом при обеспечении общественно полезного качества. Это придает хороший этичный облик ГП и м-Г и в конечном счете положительно влияет на развитие ГБ. Итак, качество складывается из тех., функционального и соц. компонентов. ММ должен помнить, что восприятие предоставленного качества клиентом - это самое главное. Клиенты оценивают предоставленные товары и ГУ исходя из своих ожиданий. Если восприятие КГУ отвечает ожиданиям, то они рассматривают обслуживание как качественное. Если же восприятие КГУ не оправдывает их ожидания, они рассматривают обслуживание как плохое. Ожидания потребителя формируются в результате его предшествующего опыта под влиянием общественного мнения, а также внешних связей фирмы и ее паблисити [6]. Существующие стандарты предписывают обеспечение качества ГП и ГУ в м-г. Цель определения и оценки КГУ заключаестя в рейтинге качества. Рассматривая качество на первом плане, как основу КПМ, имеется возможность перейти к прогрессу и процветанию и к увеличению качества, что приводит к повышению эффективности ГБ. КПМ служат предпосылкой улучшения своего положения по сравнению с конкурентами в будущем. При этом, источники КПМ - объединение и соблюдение отработанных годами навыков, традиций, а также развитие имеющихся у мини-гостиницы ресурсов, создавая ценность для клиентов. Ресурсы могут быть классифицированы как материальные (MP) или нематериальные (НР) [7]. Они позволяют гостинице осуществлять все свои мероприятия. МР: акции, материальные механизмы, здания, человеческие ресурсы и финансы. НР: навыки, знания, товарные знаки, авторские и патентные права [8]. Также могут быть включены «Бесплатные ресурсы» (БР) в контексте гостеприимства. База туризма и гостеприимства заключается в сочетании «свободных ресурсов» (т.е. возобновляемых ресурсов) с ресурсами из частного и гос. секторов [9]. БР в сочетании с редкими ресурсами составляют то, что большинство туристов понимают, как «ГП». ММ сталкиваются с особыми проблемами:

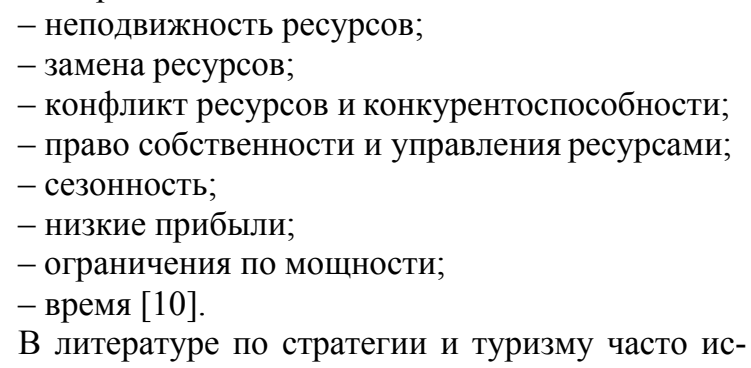
пользуют термин «поддержание, сохранение», связанный с идеей КПМ, которое достигается для тех, кто в более выгодном положении держат свои позиции, несмотря на конкуренцию (Портер, 1980) [11]. Другими словами, для того, чтобы достичь конечной цели сохранения позиций в КПМ, компания не должна копировать или имитировать др. компании [12]. В своей работе о КПМ, английский ученый Майкл Юджин Портер (1985), признанный специалист в области изучения эк. конкуренции, в том числе конкуренции на межд. рынках, конкуренции между странами и регионами, заявил, что КПМ возникает из ценности того, что компания способна создавать для своих потребителей, что превосходит расходы его создания [13]. Концепция качества приобретает важность только в случае, если ГП или ГУ отвечают требованиям и ожиданиям гостей. Действительно, это и является причиной, что все стратегии основываются на стандартах качества, вытекающих из исключительного знания гостя и его потребностей. КГУ - оценка клиентом мастерства, высокого качества или превосходства ГУ [14]. Определяющие факторы КГУ: материальные ценности, надежность, ответственность и гарантия [15]. Качество - это, прежде всего, впечатление клиента об относительном превосходстве гостиницы и ГУ, что считается одним из наиболее конкурентоспособных приоритетов менеджмента и предпосылкой для жизнеобеспечения и роста [16]. Квест за улучшением КГУ стал высоко желанной целью в сегодняшних интенсивных конкурентных РГ. Хотя очевидно, что определение КГУ - это сложнокомплексные процессы, которые могут происходить на нескольких уровнях абстракции. Основываясь на цитируемом определении качества, многие авторы считают, что уже не достаточно только выполнять просьбы клиентов; скорее необходимее восхищать и восторгать клиентов. Т.о., к примеру, качество - «это способность ГП или ГУ беспрестанно выполнять или, даже, обгонять и превосходить ожидания клиентов» [17]. Качество означает “выполнение или превосходство ожиданий клиентов в настоящее время и в будущем” [18]. Эмпирические исследования (ЭИ) доказали, что воспринимаемое КГУ должно считаться оценкой конкретной ГУ, а не пробелом между производительностью м-г и какими-то нормами и ожиданиями клиентов. Небольшая дискуссия возникла по поводу негативных аспектов качества (т.е. неудовлетворенности, диссонанса, опровержения и недовольства). Как таковая, эта система может быть использована для лучшего понимания отношений между различными подходами, применяемыми для обеспечения организаций с обратной связью на восприятие клиентов их КГУ, таких, как процедуры рассмотрения жалоб, книг жалоб и предложений, фокус-группы, представления и консультации $[19,20]$. Согласно американским ученым Брэди и Кронин [20], качественное исследование используется для выявления мнения клиентов при оценке качества взаимодействия, физической среды и итоговых размеров опыта обслуживания. Полученные данные показывают, что валентность исхода ГУ может повлиять на общие представления о КГУ и указать, что важность их размеров может варьироваться в зависимости от отраслевых особенностей. Согласно Хорватской ученой Авелини Ховьевак, НС определяют категорию отеля, и каждый гость должен быть снабжен всем тем, что подразумевает индивидуальная категория. КГУ отражается в каждой детали, в том числе путем украшения и оборудования объекта, опыта персонала, и их отношения к гостям [21]. Все эти детали должны формировать единое целое, что представляется гостям, как полный спектр ГУ, при этом КГУ - это "гроздь винограда отеля», состоящая из всех индивидуальных ГУ гостиницы [22]. Кроме того, существуют различные подходы в отношении элементов, составляющих КГУ, которое состоит 
из материальных продуктов (например, в более узком смысле, проживание), поведение персонала и его отношение к работе и окружающая среда (например, зда-ния, оборудование) [23]. В др. подходах, элементы ГУ делят на прямые (например, въезд и выезд гостя), кос-венные (например, парковка) и ключевые (например, продукты питания и напитки в ресторане) и вторичные (например, ГУ, среда). Тем не менее, некоторые считают, что характеристики КГУ специфичны; таким об- разом, ГУ не могут быть универсально классифицированы с помощью конкретных элементов. Это также подтверждается различными исследованиями. Так, исследование Школы гостиничного администрирования Университета Корнелл показало, что существует несколько составляющих качества влияют на КГУ. Наиболее важный аспект доброта персонала, затем по важности следует качество еды и напитков, состояние гостиничных номеров, их размер, внешний вид и комфорт, чистота, оперативность ГУ, местоположение и внешний вид отеля и др. [24].

Обозначены 5 основных подходов к определению категории «КГУ» [25]. С одной стороны эволюционный характер развития понимания данной категории, с другой - сформировавшиеся подходы не замещают друг друга, но продолжают развиваться, взаимно обогащаясь. Параллельно развиваются смежные с КГУ концепции: УП, ожиданий потребителя, опыта и ценности для потребителя.

Первый подход соответствует определению качества как абсолютной оценки. Одно из первых опре- делений КГУ было предложено В. Цейтамлем в 1988 г.:

«КГУ - это суждение потребителя о совершенстве или превосходстве ГУ» [26]. Несмотря на преобладание идеи о том, что составляющие КГУ являются факторами, влияющими на формирование мнения об общем КГУ, существует и др. точка зрения: КГУ - фактор высшего порядка, влияющий на то, как оценивает потребитель его отдельные составляющие. Пока недостаточно исследований, позволяющих убедительно судить о том, что является причиной, а что следствием - общее КГУ или отдельные его составляющие. Б. Шнейдер считает, что эти составляющие подсознательно влияют на формирование представления о КГУ, т. к. для этого необходим хотя бы какой-то опыт ее использования.

Второй подход распространен, сегодня сохраняет свое значение в науке и практике. КГУ - соотношение ожиданий и восприятия ГУ потребителем, когда ГУ должна отвечать его требованиям (представители: К. Грёнроос, А. Парасурман, В. Цейтамль и Л. Берри, Э. Гуммессон, Дж. Хейвуда-Фармер, А. Гобадиан, С. Спеллер, М. Джонс и др.) Т. к. представление о КГУ формируется у клиента путем сопоставления ожиданий и фактического опыта ее получения, ученые обратили внимание на то, как формируются его ожидания. К. Нэш предложил модель, основанную на идее «сервисного путешествия» (СП): полученный на предшествующей стадии процесса приобретения ГУ, формирует ожидания относительно следующего этапа (рис. 2) [27].

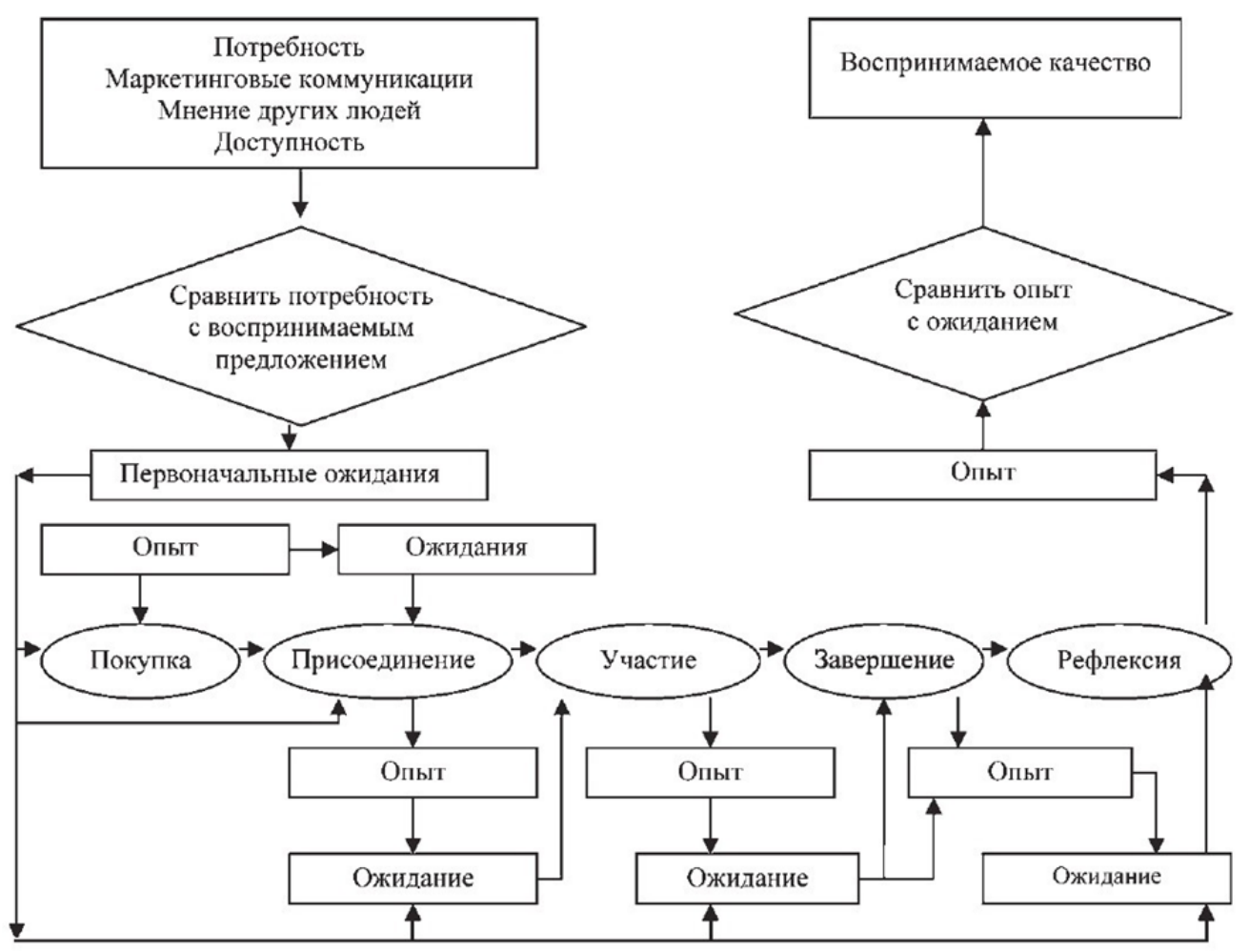

Рис. 2. Модель «СП» К. Нэша [27]

«СП» начинается с потребности потребителя (ПП). Потребитель примет решение о приобретении ГУ, если предложение будет соответствовать ПП. Точные коммуникации и репутация м-г - ключевые факто- ры, влияющие на выбор потребителем гостиницы. Важным элементом к определению КГУ является концепция опыта рассматриваемый исследователями с 2-х принципиально разных позиций. Первая основана на 
понимании опыта с глобальной точки зрения - как всей совокупности знаний, представлений и поведенческих шаблонов накопленный человеком. Сторонниками направления являются специалисты по изучению поведения потребителей и ученые-психологи (Е. Кац, Л. Ван Дер Ваген, Дж. Блайт, П.М. Чиснол и др.). Второй позиции придерживаются ученые в области управления качеством и маркетинга, рассматривающие опыт как конкретный факт взаимодействия с сервисной организацией, как опыт приобретения ГУ. С. Гупта и М. Вахик говорят, что опыт возникает тогда, когда потребитель испытывает некоторые ощущения или приобретает знания благодаря взаимодействию с различными составляющими ГУ, созданными сервисной организацией [28]. Л. Л. Бери с соавторами утверждают: опыт это и есть сама ГУ; хороший опыт использования ГУ это хорошая услуга [29]. Общей чертой обеих позиций является рассмотрение опыта во взаимосвязи с концепцией обучения. С. Онквист и Дж. Дж. Шо [30] определяли обучение как изменение поведения, происходящее благодаря изменению внешних условий и стимулов. Т.о., опыт - фактор формирования не только ожиданий, но и восприятия ГУ потребителем. Однако он оказывает влияние опосредованно - через обучение потребителя, т. е. через способность воспринимать определенные поведенческие шаблоны, изменять убеждения и отношение к окружающей среде. Л. Л. Бери с соавторами, Л. П. Карбон и С. Хекэль, М. Е. Пулман и М. А. Гросс изучают значение физического окружения, разграничивая материальный контекст (механические и функциональные факторы) ГУ и отношенческий контекст (человеческий фактор). Функциональные факторы соответствуют такому элементу КГУ, как техническое качество (в терминологии К. Грёнрооса). Механические факторы являются сенсорной частью ГУ, включающей внешний вид, запахи, звуки, вкус и другие ощутимые элементы опыта использования ГУ. Человеческий фактор отражает внешний вид и поведение сервисных служащих и соответствует функциональному элементу КГУ в терминологии К. Грёнрооса. Сумма всех факторов составляет потребительский опыт. Л. Л. Бери считает, что функциональные факторы являются основой когнитивного восприятия ГУ, в то время как механические и человеческий факторы являются основой эмоционального восприятия [31]. Согласно мнению А. А. Брогович, Л. М. Делен и Д. М. Лит, расхождение между ожиданием и восприятием может возникнуть, если потребитель даже не имел опыта приобретения ГУ в гостинице, а полагался на суждения знакомых и родных, рекламные обещания [32]. Поэтому наряду с фактическим восприятием КГУ необходимо учитывать потенциальное восприятие [33]. Т. о., второй подход рассматривает КГУ как внешний по отношению к ГУ атрибут, как мнение о ГУ, сформированное в сознании потребителя на основе сравнения его ожиданий относительно ГУ и фактического восприятия в процессе и после ее приобретения. Это динамический цикл КГУ, где основным объектом управления выступают сам потребитель и его внутренний мир - опыт, знания, эмоции, ожидание, восприятие, а материальные и нематериальные характеристики ГУ, - это фактор, инструмент воздействия на мнение потребителя.
Третий подход к определению содержания категории «КГУ», развитие которого тесно связано со вторым, основан на предположении, что межличностные отношения оказывают критически важное воздействие на качество, как результата, так и процесса обслуживания, ключевой фактор формирования ожиданий потребителей. Более 20 лет назад К.Ф. Сурпренант с соавторами утверждал, что обслуживание есть взаимодействия людей [34]. КГУ в процессе такого взаимодействия находится под влиянием точек зрения и потребителя и исполнителя ГУ. Представленная на рис. 3 модель сервисного успеха, разработанная П. Беддоуз, С. Гуллифорд, М. Найт и И. Сондерс, акцентирует внимание на важности поведенческих соображений. Одним из ведущих факторов обеспечения высокого КГУ признано достижение баланса между ожиданиями клиентов и ожиданиями сотрудников. Одна из опасностей, с которыми сталкиваются гостиницы, это раздутые усилиями маркетинговый коммуникаций ожидания клиентов, не соответствующие уровню развития гостиницы и ее персонала. В соответствии с данной моделью важнейший фактор, воздействующий на КГУ, релевантность и эффективность системы оказания ГУ. Модель позволяет определить, почему возникают проблемы с КГУ, но не дает представления о природе проблем и способах борьбы с ними. Аналогичное заключение сделал Дж. А. Чапел: исследование КГУ должно быть основано на мнении и потребителя и исполнителя ГУ [35]. Многие исследователи (А. Дедеке, Г. Свенссон, К. ЧоуЧуа и др.) основывались на изучении двух точек зрения и рассматривали интерактивные свойства ГУ в процессе обслуживания. xa [36].

На рис. 3 показана модель сервисного успе-

Б. Эдвардссон, развивая данное направление, говорил, что при определении КГУ следует учитывать ожидания и требования персонала и ММ. По его мнению, это не снижает значимости требований потребителя, однако для обеспечения высокого КГУ необходимо сбалансированно подходить к УП, их часто противоречивых потребностей всех заинтересованных сторон [37].

Новый вклад в развитие данного подхода внес шведский ученый Г. Свенссон, предложивший модель интерактивного КГУ [38]. Потребитель и исполнитель ГУ взаимодействуют в процессе обслуживания; вовторых, ожидания исполнителя ГУ и ожидания потребителя ГУ взаимозависимы; в-третьих, взаимозависимыми также являются восприятие ГУ со стороны потребителя и исполнителя. Следовательно, циклы ГУ состоят из следующих 4 компонентов: ожиданий исполнителя ГУ, восприятия исполнителя ГУ, ожиданий потребителя ГУ, восприятия ГУ потребителем. Данные компоненты циклов ГУ определяют появление 4 потенциальных расхождений: теля ГУ

1) между ожиданиями и восприятием исполнителя ГУ

2) между ожиданиями и восприятием потреби-

3) между ожиданиями потребителя и ожиданиями исполнителя ГУ;

4) между восприятием потребителя и восприятием исполнителя ГУ. 


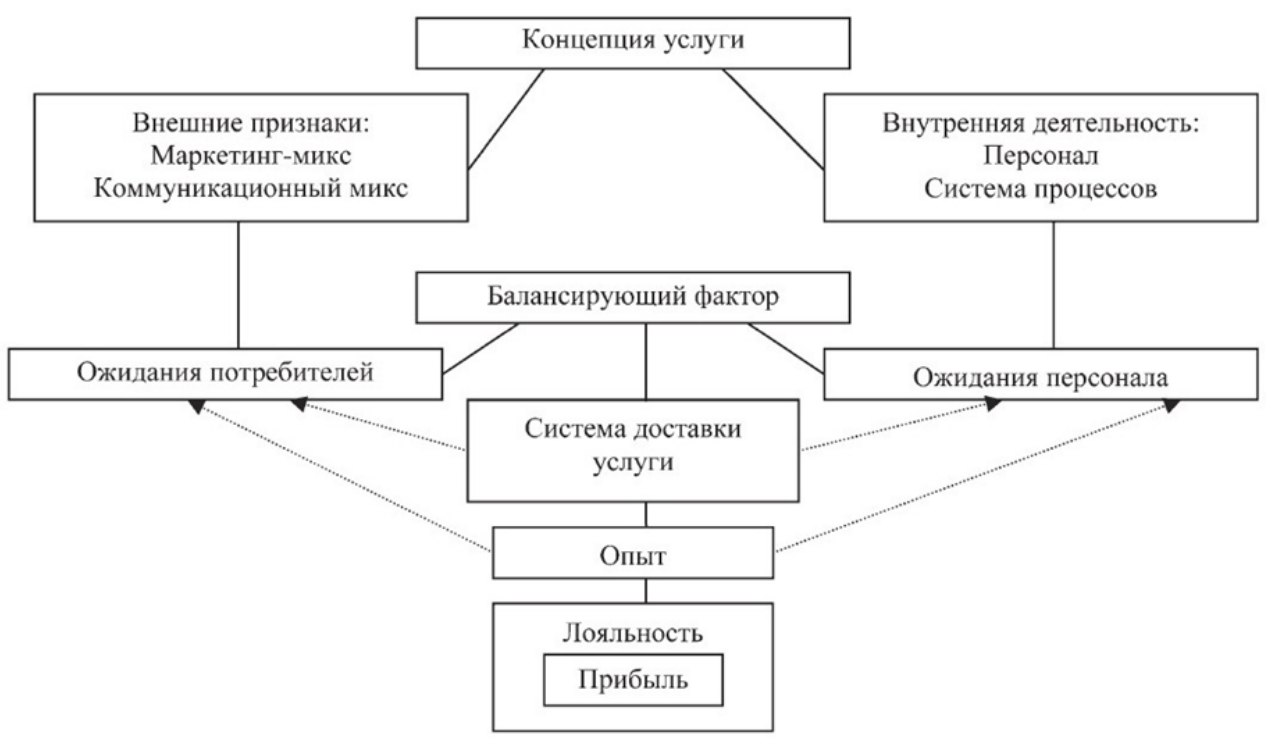

Рис. 3. Модель сервисного успеха [36]

Интерактивное КГУ - удовлетворительное, если согласованы циклы ГУ потребителя и исполнителя в процессе обслуживания. Отсутствие расхождений не свидетельствует об идеальной ситуации. Желательно, чтобы существовал диссонанс, указывающий на то, что цикл потребителя положительно превосходит цикл исполнителя. В 2004 г. Г. Свенссон продолжил исследования интерактивной сущности КГУ. Согласно которому, КГУ - результат серии последовательных процессов взаимодействия потребителя и исполнителя ГУ [39]. Такой подход во многом соответствует концепции «сервисного путешествия», когда опыт, приобретенный потребителем на предыдущем этапе сервисного процесса, влияет на формирование ожиданий относительно следующего этапа. Т.е. третий подход к определению КГУ - продолжение второго, т.к. он также основан на сопоставлении ожиданий и восприятия; в качестве ключевого фактора, влияющего на их формирование, рассматривается опыт; в рамках данного подхода придерживаются динамического взгляда на формирование КГУ. Хотя при определении КГУ учитываются ожидания и восприятие потребителей и персонала и их взаимное влияние.

Четвертый подход сформирован на основе критического анализа второго. Его первыми представителями можно признать Дж. Кронина и С. Тейлора, которые в 1992 г. в ходе длительных исследований пришли к заключению, что КГУ является формой потребительского отношения к ней, и поэтому оно должно оцениваться исключительно путем измерения восприятия клиентом ГУ и ее отдельных свойств. Они считали, что представители первого направления путают УП и отношение, и предложили определять КГУ как восприятие ГУ потребителем и отношение к ней. Данную точку зрения поддерживали П. А. Дабхолкар, С. Д. Шеферд, Д. И. Торп [40]. На основе ЭИ они выяснили, что результаты оценки КГУ только на основе восприятия показали более высокие, со статистической точки зрения, надежность и достоверность и лучшую прогностическую способность. Хотя широкого признания данный подход не получил, его применение сводится к использованию в КГУ основы модели 8ЕЯУРЕКЕ, на- правленной на оценку КГУ путем измерения восприятия ГУ потребителем.

Пятый подход сформулирован Дж. Кронин и С. Тейлор в начале 1990-х гг.: клиент не всегда приобретает ГУ наилучшего качества, а принимает решение о покупке на основе представления о ценности ГУ, объекта изучения нового направления. Первоначально ценность ГУ рассматривалась как результат сравнения тех выгод и положительного опыта, которые приобрел клиент, и затрат, которые ему пришлось понести. Дрогого взгляда придерживались В. Цейтамль, Р. Хаксевер, Дж. Суинни, Г. Ох, Дж. С. Суинни, Г. Н. Соутар, Л. У Джонсон. Существуют две альтернативные точки зрения относительно соотношения КГУ и ценности. Согласно первой, КГУ - один из компонентов ценности для клиента. Так, в соответствии с подходом В. Цей-тамля модель ценности ГУ включает воспринимаемое КГУ, внутренние признаки (выгоды, которые предоставляются клиенту), внешние выгоды (имидж м-г), денежную цену и неденежные затраты на приобретение ГУ. К. Хаксевер, Б. Рендер, Р Рассел, Р. Мердик расширили данную модель, добавив время как 6-ю компоненту [41]. Вторая точка зрения предполагает, что КГУ влияет на восприятие потребителем ценности ГУ. Такой подход соответствует модели «ценность за деньги»: наряду с КГУ и ценой восприятие тех. КГУ напрямую влияет на восприятие потребителем ценности ГУ. При этом восприятие функционального КГУ непосредственно воздействует на намерение потребителя приобрести ГУ и на восприятие тех. КГУ и опосредованно - на восприятие общего КГУ. Иной взгляд на формирование ценности предлагает канадский ученый Дж. Мэттссон, который считает, что представление о ценности ГУ складывается у потребителя на основе сравнения фактического опыта приобретения ГУ и некоторого идеального стандарта, существующего на подсознательном уровне [42]. Поэтому развитие данного направления связано с изучением «покупательского опыта» как основного фактора, влияющего на формирование ценности, а также с переходом от концепции «ценности за деньги» к концепции «ценности в использовании», предложенной в 2004 г. американскими уче- 
ными С. Варго и Р. Лашем, которая показывает, что представление о ценности ГУ сугубо индивидуально для каждого клиента и формируется в процессе ее получения или использования. Это означает необходимость признания клиента сопроизводителем ценности и ее основным судьей [43]. С.Л. Варго и РФ. Лаш акцентируют внимание на ключевой роли потребителя в процессе создания ценности. Создавать ценность взаимодействовать с потребителем и учиться у него адаптироваться к индивидуальным и постоянно меняющимся ПП. М-г может только создать ценностное предложение (ЦП), а потребитель должен определить ценность и участвовать в ее создании через процесс потребления. Ценность не будет реализована, пока потребитель не примет участия в действиях, составляющих ГУ, и пока он не воспользуется ГУ. В результате м-г больше не могут действовать автономно, разрабатывая ГУ без участия потребителя. Потребители должны быть активными участниками создания ценности, вовлечены в процессы определения и создания ценности. Созданный с участием потребителя опыт использования ГУ становится основой ценности [44]. Ценность ГУ уникальна для каждого отдельного потребителя, это результат того, какой опыт использования ГУ получает клиент. Согласно С. Варго и Р. Лаш: опыт использования ГУ не существует, пока клиент не ис- пытает его. Поэтому м-г не может заранее создать ни опыт, ни ЦП, а лишь предложить клиентам условия для получения опыта и формирования ценности, ЦП. От- каз от признания взаимосвязи стоимости ГУ и ее цен- ности привели к тому, что последняя сводится к вос- приятию ГУ клиентом, что совпадает с определением КГУ Дж. Кронин и С. Тейлор в рамках 4-го подхода. Рассмотренные подходы систематизированы авторами [25] с точки зрения объекта, по отношению к которому формируется суждение субъекта, и ключевых фак- торов, влияющих на данное суждение (рис. 4).

\begin{tabular}{|c|c|c|c|c|c|c|}
\hline & $\begin{array}{c}\text { Превосходство } \\
\text { услуги }\end{array}$ & ожидания & восприятие & ценность & опыт & $\begin{array}{c}\text { Составляющие } \\
\text { качества }\end{array}$ \\
\hline \multicolumn{7}{|c|}{ Качество как абсолютная оченка } \\
\hline \multirow{2}{*}{\multicolumn{7}{|c|}{$\begin{array}{l}\text { Суждение } \\
\text { потребителя } \\
\text { Качество как соответствие ожсиданий восприят }\end{array}$}} \\
\hline & & & & & & \\
\hline \multirow{2}{*}{\multicolumn{7}{|c|}{\begin{tabular}{l|l|} 
Суждение & \\
потребителя &
\end{tabular}}} \\
\hline & & & & & & \\
\hline \multicolumn{7}{|l|}{$\begin{array}{l}\text { Суждение } \\
\text { потребителя }\end{array}$} \\
\hline \multicolumn{7}{|l|}{$\begin{array}{l}\text { Суждение } \\
\text { исполнителя }\end{array}$} \\
\hline \multicolumn{7}{|c|}{ Качество как соответствие восприятио } \\
\hline \multirow{2}{*}{\multicolumn{7}{|c|}{\begin{tabular}{l|l|l}
$\begin{array}{l}\text { Суждение } \\
\text { потребителя }\end{array}$ & \\
Качество как соответствие ченности \\
\end{tabular}}} \\
\hline & & & & & & \\
\hline \multicolumn{7}{|l|}{$\begin{array}{l}\text { Суждение } \\
\text { потребителя }\end{array}$} \\
\hline
\end{tabular}

Рис. 4. Систематизация подходов к определению КГУ по объекту и ключевым факторам формирования суждения об объекте: 1 - объект суждения о КГУ, формирующее субъект оценки; 2 - основной фактор, влияющий на формирование суждения

Согласно рис. 4, пятый подход интегрирует все ключевые концепции определения КГУ, а восприятие потребителя - ключевой компонент суждения о КГУ, т. к. участвует в его создании с позиции четырех подходов, что подтверждает субъективную и ситуативную природу категории КГУ.

\section{3. Цель и задачи исследования}

Цель и задачи исследования - определить факторы УКМ.

Для достижения поставленной цели необходимо выполнить следующие задачи:

- рассмотреть качественные характеристики КПМ г. Киева, перспективу сохранения и развития КПМ на РГУ;

- дать анализ действующего УЗ, касающегося КГ и классификации, орг.-правовых основ создания м-г и, на основании анализа УЗ, сделать выводы, которые помогут ММ разобраться в тонкостях нормативной базы и избежать возможных проблем с налоговыми органами, судом и др. КГО;

- систематизировать научные подходы к определению понятия «КГУ». Определить основные подходы, выявить их суть, сходства и отличия, исследовать связанные с КГУ понятия: опыт, ценность, ожидание, восприятие потребителя;

- раскрыть сущность понятия КПМ;

- провести анкетирование в 70 м-г;

- изучить корреляцию достижения КПМ с позиций повышения КГУ путем увеличения категории на 1 *.

\section{4. Материалы и методы исследований}

Эта статья представляет результаты исследований об управлении м-г. Исследования проводились авторами настоящей статьи, на разовом, целенаправленно избранном образце. Целевыми группами в данном исследовании являются ММ. Данные были собраны путем проведения анкетирования 70 ММ с помощью специально структурированной анкеты. 
Хорошо известно, что размер объекта определяется количеством номеров, из которых он состоит. Гостиницы в Киеве наиболее часто классифицируются на 3 группы: м-г (5-50 номеров), средние гостиницы (51200 номеров) и большие гостинцы (более 200 номеров). Исследуемые объекты размещения образца входят в категорию м-г, имеющих менее 50 жилых номеров.

Пилот-исследования были предприняты для того, чтобы выбрать надежную выборку. Исследования, основанные на полученных результатах, должны помочь определить стандартное отклонение (СО) ' $\sigma$ ' и относительную погрешность (ОП) 'е' используя следующее уравнение:

$$
\mathrm{s}=\left[\mathrm{r}^{*} \sigma / \mathrm{e}\right],
$$

где s - Размер образца мини-гостиниц (sample size); r Коэффициент надежности (0.96) КГУ (reliability); $\sigma-$ СО КГУ; е - ОП (error).

Мы можем определить размер образца, который должен быть рассмотрен. Оценка будет дана с надежностью $95 \%$, что означает, что указанная формула использует значение 0,96 для коэффициента надежности $(0-1=0,96)$.

Значение 3 \% ОП, как правило, переносится в оценку. Поскольку СО не известно, оно тоже должно быть запланировано и оценено. Поскольку элементы почти каждого распределения были включены в диапазоне $6 \mathrm{CO}$, предполагается, что оценки СО могут быть достигнуты с тем, чтобы принять ряд во внимание для удовлетворения критериям. Диапазон варьируется от 0,23 (23\%) до 0,92 (92\%), что делает медиану 0,69 (69 \%). Указанные данные являются результатом исследований, проведенных в 70 м-г г. Киева. Они показывают, что:

$$
\sigma=0,69 / 6=0,115 \text {. }
$$

Подставив значения в выражение 1, получим следующий результат:

$$
\mathrm{s}=\left[0,96^{*} 0,115 / 0,03\right]=13,54 .
$$

Минимальный размер выборки $\mathrm{s}$ (м-г) должен быть рассмотрен при определенных условиях (например, параметры). В исследование были включены

70 м-г $(\mathrm{s}=70)$, что на порядок выше, чем требуемое число $(13,54)$; Т. о., результаты проведенных исследований считаются надежными. Наибольшее количество MМ нанимают до 20 чел. (86,7 \%). Наибольшее группа внутри структуры включает от 10 до 19 чел. (38,3\%), далее следуют МM, с 6-9 чел. (31,7 \%), и 1-5 чел. $(16,7 \%)$. Наибольшее количество чел. в образце -43 . При сравнении типа и категории гостиниц, можно сделать вывод, что наибольшее число - это небольшие гостиницы $3 *(50 \%)$. Второе место - 4* $(25 \%)$ и $5 *(25 \%)$.

Методы исследования базируются на двух основных принципах, которые полагаются на использование описательного и логического вывода анализа. Методы множественного регрессионного анализа были использованы, чтобы показать роль качества в УКМ в Киеве. SPSS версия пакета 11,0 была использован для анализа данных [45]. Надежность оценивали с помощью коэффициента альфа Кронбаха, который представляет собой меру внутренней согласованности.

\section{6. Результаты исследований}

Сортируя влияние индивидуальных особенно- стей на КПМ, авторы настоящей статьи использовали статистический подход к обработке данных, основная цель которого - установление возможности определения надежного показателя собранных данных КПМ и установление соответствующей роли в повышении категории отеля на одну звезду, как одного из предсказателей КПМ.

В 1994 г. Гос. Комитетом Украины по туризму было издано «Положение о гос. аттестации и перерегистрации гостиниц, мотелей, кемпингов, туристских баз и комплексов, а также предприятий общественного питания Украины, которые принимают и обслуживают туристов». В основе Положения лежит европейская система классификации системы звезд, которой соответствуют определенный уровень материальнотехнической базы, уровня обслуживания и т.д. Высшая категория определялась в «5*» $(* * * * *)$, низшая «1*» $\left(^{*}\right)$. В 1994 г. в России был разработан по Европейскому типу новый ГОСТ Р50645-94 «Туристскоэкскурсионное обслуживание. Классификация гостиниц». 25.04.1995 г. 10 членами Совета по СМС, действующего в рамках СНГ этот ГОСТ был принят для использования в своих странах. Приказом Госстандарта Украины № 99 от 04.03.1996 г. этот ГОСТ 28681.4-95 «Туристско-экскурсионное обслуживание. Классификация гостиниц» был введен в действие в Украине с 01.01.1997 г. ГОСТ устанавливает классификацию гостиниц (мотелей) различных орг.-правовых форм вместимостью не менее 10 номеров. Классификация не распространяется на дома и помещения, сдаваемые в наем для проживания. В ГОСТ содержатся общие требования к гостиницам: классификация гостиниц осуществляется по категориям и основана на комплексе требований к:

- мат.-тех. обеспечению; -номенклатуре и КГУ;

- уровню ГУ. Категория обозначается специальным символом - «*» (звезда).

Количество звезд увеличивается в соответствии с повышением уровня КГУ. Гостиницы классифицируют по 5 категориям, мотели - по 4. Высшую категорию обозначают «*****»; низшую «*».

В Украине есть четкие требования, которым должны соответствовать гостиницы, установленные НС Украины ГОСТ ДСТУ 4269:2003 и Hotelstars Union. Требования для гостиниц категория 1-5* приведены ниже:

Гостинииьл $1 *$ :

- отдельные входы для отдыхающих и для персонала гостиницы;

- парковка, с количеством мест, равном $10 \%$ или выше от количества номеров;

- зданиях высотой более 3 этажей должен быть лифт;

- санузел (ванная/душ, туалет) - не менее чем в $25 \%$ от общего количества номеров;

- санузел - на каждом этаже гостиницы;- количество одноместных и двухместных номеров - не менее $60 \%$ от всех номеров;

- в приемной - зоны отдыха и ожидания;

- площадь одноместных номеров -8 кв. м, двухместных - 12 кв. м;

- комплект постельных вещей и постельного белья: матрац и наматрацник, 2 подушки, одеяло, до- 
полнительное одеяло, покрывало на кровать, простынь, пододеяльник, наволочки;

- коврик возле каждой кровати (по обе стороны) в случае отсутствия ковра или коврового покрытия на полу;

- тумбочка (столик) возле каждого спального

места;

- вешалка для верхней одежды и головных уборов;

- стулья или др. мебель для сидения (по одному на каждого гостя, но не менее 2 в номере);

- коврик на полу в санузле;

- не менее 2 полотенец на каждого гостя;

- стаканы для каждого гостя;

- стол или письменный стол;

- телевизор по требованию гостя. Общие требования к качеству оборудования и оснащения гостиниц $1 *$.

Гостиницы категории 1 * могут быть построены из недорогих строительных материалов, иметь оборудование и мебель, выпушеные серийно, но вся мебель и электрооборудование должны быть исправны, функциональны. Постельное белье и полотенца должны быть качественные, без поврежений. Санузлы должны быть оборудованы исправным оборудованием, стены и пол покрыты водонепроницаемым материалом. (ДСТУ 4269:2003.) Критерии Hotelstars Union: наличие ванны/душевой кабинки и туалета во всех номерах.

Гостиницы 2* (помимо всех вышеуказанных требований должны также присутствовать):

- ресторан или кафе (для гостиниц с количеством номеров более 50);

- многокомнатные номера или возможность соединения нескольких номеров при такой необходимости;

- наличие санузла, как минимум, в половине номеров;

- количество одно/двухместных номеров - не мене $80 \%$ от всего номерного фонда.

Общие требования к качеству оборудования и оснащения гостиниц $2 *$ : Все оборудование гостиницы может быть недорогое, но функциональное, исправное, в хорошем техническом состоянии. Постельное белье в хорошем состоянии, не изношенное, без повреждений, из натуральных или натурально-искусственных тканей: может быть однотонное или с рисунком, белое или цветное, клетчатое или в полоску. Оснащение санузлов должно иметь эстетический вид, стены и пол покрыты водонепроницаемым материалом и сделаны качественно, без видимых недостатков. (ДСТУ 4269:2003.) Критерии Hotelstars Union: предоставление гигиенических средств (зубная щетка, зубная нить, набор для бритья).

Гостиницьь $3 *$ - являются гостиницами нового качественного уровня. Помимо указанного набора услуг отель должен предложить: аппаратурой;

- конференц-зал, оборудованный необходимой

- парковку или гараж, рассчитанные на количество мест, составляющих не менее $20 \%$ от номерного фонда;

- парикмахерскую;

- бар/ресторан;

- в гостиницах этого класса все номера должны быть оборудованы санузлами;
- все номера только одноместные (площадь

9 кв. м) или двухместные (14 кв. м);

- не менее 3 полотенец на каждого гостя (кроме отелей $4 *, 5 *)$;

- шапочка банная на каждого гостя;- цветной телевизор в каждом номере.

Общие требования к качеству оборудования и оснащения гостиниц $3 *$ : Здание гостиницы должно органично вписываться в архитектурный ансамбль улицы (площади), главный фасад здания должен соответствовать определенному архитектурному стилю. Если здание построено по неудачному проекту и оно имеет невыразительный фасад, должен быть применен широкий спектр современных строительных технологий и материалов, которые дают возможность сделать внешний вид привлекательным. Мебель и оборудование могут быть из материалов средней стоимости, но хорошо оформлены и соответствовать единому стилю. Все оборудование должно быть в хорошем техническом состоянии и создавать уют. Номера и общественные помещения украшают декоративными элементами, картинами или другими художественными произведениями. Постельное белье из натуральных тканей, не изношенное, однотонное или с рисунком, белое или цветное, клетчатое или в полоску. Санузлы оборудуют качественным оборудованием средней стоимости, стены и пол покрыты водонепроницаемым материалом, сделаны без недостатков. (ДСТУ 4269:2003.) Критерии Hotelstars Union:- телефон в номере;- интернет-доступ в номере или на ближайшей к нему территории;- двуязычный персонал (нем. и англ. языки);- приемная в гостинице открыта 14 часов, 24 часа - доступна по телефону.

B гостиницах 4* (в дополнение к предыдущим ГУ должны быть):

- сауна;

- косметический кабинет;

- ресторан с несколькими залами;

- площадь одноместных номеров 16 кв. м, двухместных - 20 кв. м;

- ванна (не душевая кабинка) в санузлах;

- ковер или ковровое покрытие пола;

- кресло для отдыха (как минимум два на но-

мер) или мягкий диван;

- не менее 4 полотенец на каждого гостя;

- фен для сушки волос;

- набор посуды для питьевой воды, чая и минибара;

- журнальный столик;

- письменный стол со стулом или рабочим креслом.

Общие требования к качеству оборудования и оснащения гостиниц $4 *$ : Здание гостиницы должно органично вписываться в архитектурный ансамбль улицы (площади). Все фасады здания должны соответствовать определенному, четко выраженному архитектурному стилю; в случае реконструкции здания - исторически-архитектурного памятника, необходимо сохранить начальный вид фасадов, фресок, витражей. Интерьер здания создается в соответствии с единым дизайн-проектом, стены украшают художественными произведениями, гармонирующими с интерьером. Строительные материалы, мебель и оборудование об- 
щественных помещений и номеров должны быть из дорогих материалов, комфортные и в очень орошем тех. состоянии. Во всех помещениях должны быть ковры или ковровые покрытия отличного качества. Постельное белье из тонкотканных натуральных тканей, белое или цветное. Санузлы оборудованы качественным дорогим оборудованием в отличном состоянии, стены и пол покрыты водонепроницаемым материалом не менее чем на две трети поверхности по высоте. (ДСТУ 4269:2003.) Критерии Hotelstars Union:

- вестибюль с местами для отдыха;

- мини-бар;

- банный халат/тапочки, разнос напитков по требованию;

- доступ к интернет;

- приемная открыта 18 часов, 24 часа доступна по телефону.

Гостиницы $5^{*}$ (помимо всех предыдущих требований):

- бассейн с сауной;

- медпункт;

- ночной клуб;

- площадь одноместных номеров - не менее

- 18 кв. м, двухместных - от 25 кв. м;

- банный халат и банные тапочки на каждого гостя;

- мини-сейф в каждом номере.

Общие требования к качеству оборудования и оснащения гостиниц $5 *$ : Требования к зданию такие же, как к гостиницам категории 4*. Исключительный дизайн интерьера. Номера, холы, вестибюль украшены авторскими работами: картинами, декоративными украшениями, керамикой, гобеленами и т. п. Предметы интерьера и оформление создают респектабельную атмосферу. Общее оборудование, оборудование общественных помещений, комнат и санузлов, мебель и ковры должны быть из самых дорогих материалов, иметь собственные неповторимые особенности и находиться в безупречном состоянии. Посуда и столовые приборы должны быть одного стиля, гарнитурные. Постельное белье из тонкотканных натуральных тканей с вышитой или вытканной эмблемой гостиницы (ДСТУ 4269:2003.) Критерии Hotelstars Union:

- приемная открыта 24 часа;

- многоязычный персонал;

- услуги консьержа и парковка авто служащим гостиницы;

- просторный холл с местами для сидения, сервисом разноса напитков;

- мини-бар, доставка еды и напитков по заказу круглосуточно;

- приветствие каждого гостя, свежие цветы/подарок в номере.

Только при удовлетворении всех требований возможно присвоение гостинице определенной категории.

На рис. 5 отобразим КПМ.

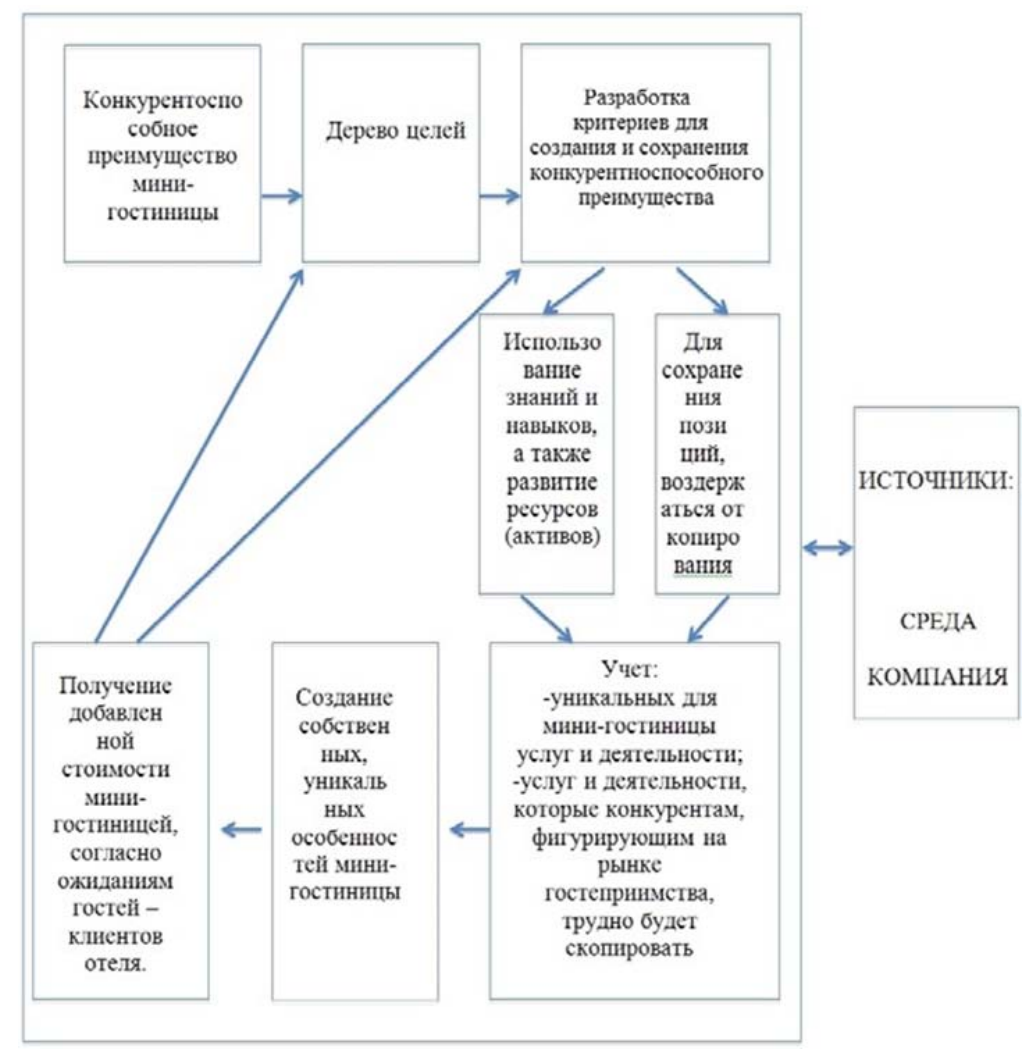

Рис. 5. Конкурентное преимущество мини-гостиниц

КПМ формируются благодаря деятельности, функциям и качествам м-г, которые лучше, чем у их конкурентов. Создание КПМ можно определить только по сравнению с конкурентами, это значит, что м-г необходимо создать больше ценности, чем у конкурен- тов. Существует 2 критерия для создания и сохранения КПМ [46]:

- деятельность, уникальная для м-г, помогающая ей производить ГП и оказывать ГУ, ценимые потребителями; 
- конкурентам сложно скопировать их. М-г, поддерживающие КП, в первую очередь те, которые обладают прочностью и возможностями для быстрого преобразования ГУ.

Ключ к успеху - обеспечение УП за счет развития навыков, знаний и процессов, легко адаптируемых к изменчивым ПП. Существующая концептуализация понятия КГУ доказывает ее сложность и дальнейшее развитие. На основании ранее проведенных исследований, авторы этой статьи установили следующие утверждения: У1: Качество гостиничного обслуживания напрямую зависит от качества отдельных ГУ. У2: Восприятие КГУ напрямую связано с восприятием качества обслуживания. У3: С повышением КГУ, КПМ будет увеличиваться. У4: Увеличивая категорию м-г на 1 категорию (рейтинг звезд), КПМ будет увеличено. Для проверки этих утверждений, авторы рассмотрели документы исследования (в рамках исследования уровня и качества) качества м-г среднего класса по сравнению со всем жильем Киева и реализацию качества в гостиницах. Классификация и ранжирование отельного качества оценим по шкале: от $3 *$ до $5 *$. Критерии получения средних оценок гостиниц - их число и категория.

Кроме того, существует следующая средняя оценка КГУ средних и крупных гостиниц по сравне- нию с 70 м-г, взятых в нескольких городах Украины, включая г. Киев, данные представлены в табл. 1.

Таблица 1

Средняя оценка КГУ средних и крупных гостиниц по сравнению с 70 м-г, взятых в нескольких городах Украины, включая г. Киев

\begin{tabular}{|c|c|c|c|c|}
\hline Гостиницы & $3^{*}$ & $4^{*}$ & $5^{*}$ & Средняя оценка \\
\hline $\begin{array}{c}\text { Гостиницы } \\
\text { всех категорий }\end{array}$ & 315 & 142 & 23 & 3.14 \\
\hline М-г & 30 & 25 & 15 & 3.75 \\
\hline
\end{tabular}

Источник - исследование авторов

Отсюда следует, что КГУ м-г выше по сравнению с КГУ средних и крупных гостиниц, а, следовательно, необходимо развивать м-г и упрощать законодательные процедуры, касающиеся классификации, КГ, открытия и функционирования м-г. Средние оценки КГУ всех категорий м-г, в соответствии с указанным сравнением, является 3,14 и является относительно низким, принимая во внимание ПП. Примеры м-г демонстрируют, что их средний балл КГУ выше по сравнению со средней оценкой обычных гостиниц $(3,75)$. Это связано с инвестициями в м-г и улучшением КГУ благодаря строительству новых гостиниц. При этом, необходимо принять во внимание тот факт, ММ заботятся о их качестве самостоятельно (96,7 \% или 58), в то время как только 3,3 \% ММ используют внешние услуги консультантов, связанные с качеством. Хотя ММ отмечает, что качество - их основная стратегическая цель, исследования показали, что стратегия качества практикуется только на декларативном уровне. Т. о., ММ имеет постоянную задачу внедрения и сравнения качества в бизнесе. Хотя категория здания м-г представляет тех. элементы и включает статический элемент качества, как необходимый элемент качества, но ориентированные на рынок динамические элементы качества, адаптированные к ПП, подвержены постоянным изменениям.

Развитие современных видов туризма, приводит к повышению разнообразия коллективных СР, прежде всего, гостиниц, что приводит к появлению различных подходов к структуризации и сегментации гостиничного хозяйства, согласно которым выделяются различные группы СР. На Украине действует «Порядок предоставления услуг по временному размещению (проживанию)», согласно которому, все СР подразделяются на коллективные (КСР) (вместимостью свыше 10 мест) и индивидуальные (ИСР) (до 9 мест включительно), в результате чего для каждой из 2 групп выработан определенный механизм регистрации, функционирования, ведения налоговой, статистической и др. видов отчетности [47] КСР:

1) гостиничного типа: гостиницы, мотели, пансионаты, пляжные гостиницы, клубные номера, гостевые дома, др.;

2) специализированные: гостиницы при лечебных заведениях, лагеря труда и отдыха, транспортные СР, приюты и хижины, конгресс-центры, др.;

3) др: тур. базы, хостелы, тур. деревни, кемпинги, бунгало, др. ИСР:

4) частные, частное жилище (квартиры, виллы, коттеджи), арендуемые комнаты в частных домах, арендуемые помещения у частных агентов, размещение у родственников и знакомых, др. [48].

На долю всех гостиниц приходится до 65 \% лиц, занятых в тур. сфере, и около 68 \% всех поступлений от туризма. Появление новых м-г значительно повышает привлекательность региона, увеличивая поток туристов. От КГУ по размещению зависят такие психологические аспекты туризма, как высокая оценка организации пребывания ИТ и УП.

Гостиницы обладают своими характерными признаками:

- состоят из номеров, число которых превышает определенный минимум (обычно 5 и более номеров), имеют единое руководство;

- предоставляют разнообразные ГУ, перечень которых не ограничивается ежедневной заправкой постелей, уборкой номера и санузла;

- сгруппированы в классы и категории в соответствии с предоставляемыми ГУ, имеющимся оборудованием и стандартами страны;

- не входят в категорию специализированных заведений (лагеря, приюты и т. д.) [49].

Согласно ДСТУ 4268:2003 «Услуги тур. СР. Общие требования» гостиница должна иметь вместимость от 7 и более номеров (ДСТУ 4268:2003), а в соответствии с ДСТУ 4527:2006 «Услуги тур. СР. Термины и определения» были узаконены такие типы гостиниц, как, например, «агрогоотель», «акватель», «апартотель», «ботель», «флотель», «гостинично-офисный центр», «курортная гостиница», «мотель», «отельлюкс», «отель-резиденция», «палац-отель», «конгрессотель», «хостел» и т.п. (ДСТУ 4527:2006) [50]. Однако термина «малая гостиница» (или «малый отель», «М-г») в УЗ не существует, как не существует требований, соблюдая которые ММ или арендаторы малоформатных средств размещения могли бы внести весомый 
вклад в развитие тур. Бизнеса Украины. Параллельно с понятием «гостиница» все чаще используется понятие «отель», которым принято называть гостиницу более высокого уровня с широким спектром и высоким КГУ, создающую повышенный комфорт и атмосферу госте- приимства.

ГБ - одна из наиболее быстро развивающихся отраслей, на которую приходится около $6 \%$ мирового ВНП и около 5 \% всех налоговых поступлений. Его развитие стимулирует развитие др. направлений: транспорта, торговли, строительства, сельского хозяйства, производства товаров народного потребления, сферы услуг и т. д. В среднем, на каждые 10 туристов, проживающих в гостинице, приходится около 3 рабочих мест напрямую, и 2 рабочих места, косвенно связанных с обслуживанием (сотрудники турфирм, транспортных компаний и т. д.). Общемировой гостиничный фонд составляет около 17-18 млн. мест, и данный показатель постоянно растет. ГБ привлекает предпринимателей по многим причинам: относительно небольшие стартовые инвестиции, растущий спрос на тур. услуги, высокий уровень рентабельности и, соответственно, средний срок окупаемости затрат. За последние 3 г., благодаря увеличивающемуся потоку туристов, мировой ГБ переживает настоящий рост - загрузка отелей и стоимость размещения заметно выросли, гостиницы расширили свое присутствие по всему миру. Быстрыми темпами растет и укр. РГ. Наиболее востребованными на Украине являются гостиницы уровня $3 *$, гостиницы эконом-класса, общежития и гостиницы, попавшие в категорию др., к которой также относятся м-г. В сфере туризма малый ГБ может успешно разви- ваться небольшими по емкости СР. В связи с тем, что гостиницы можно классифицировать по такому критерию, как единоразовая вместимость, специалистами в сфере туризма выделяются крупные, средние и м-г. Однако в нормативно-правовых актах действующего УЗ термина «М-Г» не существует, хотя в практике ведения отечественного ГБ он начал применяется несколько лет назад. Что касается зарубежного опыта, то гостиницы малых форм получили широкое распространение во всем мире. В странах Европы м-г не только прочно заняли свою нишу, но и стали одним из ключевых элементов РГ. Эволюция ГБ в Старом Свете привела к появлению эмпирической пропорции 3:2 в об- служивании клиентов крупными и малыми СР, т. е. большую часть (около 60 \%) постояльцев обслуживают большие гостиницы, а $40 \%$ туристопотока приходится на средства размещения малых форм. В отношении структуры СР по количеству гостиниц ситуация иная - в странах Европы большие отели составляют лишь 15- 25 \% общего количества гостиничных предприятий, в то время как 75-85\% приходится на малые мотели и отели семейного типа.

Эталоном в сегменте м-г считаются м-г Франции, каждая из которых обладает уютом и уникальностью в сочетании с умеренными ценами. Все гостиницы этой страны подразделяются на 6 категорий (от 1 до $4 *$ «люкс» и некатегорийные). При этом размер гостиницы практически не оказывает влияния на категорию, так как потребитель получает отдельный номер, и только его оборудование и набор услуг являются критериями оценки (Сенин, 2005). Наглядным примером также может служить одна из родоначальниц гости- ничного бизнеса - Швейцария, львиная доля ее гостиниц приходится именно на м-г, что связано с историей создания гостиниц в этой стране и спецификой нации, умеющей хранить многовековые традиции [51]. Примечателен опыт Великобритании, в которой м-г - существенный стимул для развития отрасли и создания дополнительного количества рабочих мест. Среди британских СР существует большой процент м-г, расположенных по всей стране. Так, гостевые, фермерские дома и маленькие придорожные отели (Inn) предоставляют ГУ, объём которых соответствует уровню $1 *$. Ещё одним примером бурно развивающегося м-г является Россия, в некоторых регионах которой отмечаются прогрессивные тенденции увеличения мощности гостиничного хозяйства за счёт вовлечения в данную сферу малоформатных СР. Безусловными лидерами в деле развития м-г являются Краснодарский край и СанктПетербург, в Питере, по данным Центра развития малых отелей за 2007 г., функционирует более 500 м-г с числом номеров от 2 до 40 (для сравнения: в Москве на сегодняшний день, действуют только 65 м-г). Следует отметить, что в нормативных документах Ростуризма пока нет словосочетания «малая гостиница» или «малый отель», но вводится понятие - «гостиницы, мотели и пр. с количеством номеров менее 50» [52]. При этом внутри российского РГ условно сложились 2 определения: «малый отель», - гостиница, имеющая до 50 номеров, и «мини-отель» - до 10 номеров (в то время, как по российскому законодательству в сфере гостиничного хозяйства, к категории гостиниц относятся СР, имеющие более 10 номеров). По данным Praktis Consulting\&Brokerage, мини-гостиницы СанктПетербурга уже занимают долю в 20 \% в общем номерном фонде города, обслуживая 25-30 \% туристопотока [52]. Что касается г. Киева и Украины в целом, в настоящее время во многих регионах Украины появляются м-г, успешно конкурирующие с большими СР, т. к. могут предложить туристам более качественное, персонифицированное обслуживание на фоне более низких цен. О росте популярности не узаконенных на официальном уровне м-г свидетельствует тот факт, что ин. туристопоток в Украину на протяжении последних лет постоянно увеличивается - с 6,4 млн. прибытий в 2000 г. до 23,1 млн. в 2007 г., - а коэффициент загрузки средств размещения, по официальным данным, остаётся на уровне - 29 \% [53]. Т.о., преобладающее число как ин., так и внутр. туристов расселяется в частном секторе, представленном ИСР, или незарегистрированными в качестве СПД «малоформатными» гостиницами, работающих без оформления разрешительных документов. Спрос на ГУ верхнего ценового сегмента (4$5^{*}$ ) состоит из ИТ, доля потребления $-80 \%$.

\section{7. Обсуждение результатов}

В сегодняшней все более открытой и интегрированной мировой экономике, КМ имеет центральное место в эк. мышлении как в развитых странах, так и в странах с переходной экономикой. Преимущества м-г многочисленны. С их гибкостью, креативностью и динамикой, они обеспечивают основу для достижения КП. Маленькие м-г создают добавленную стоимость, обеспечивая тем самым конкурентоспособность своей собственной позиции на РГ. Хорошо известно, что м-Г 
РГ - основа развития, ядро для нового трудоустройства, а экспорт - это мощь страны. М-г подчеркивают их адаптацию и гибкость на РГ путем создания пространства, в котором новые решения могут быть найдены, чтобы дополнительно повысить конкурентоспособность этого сектора.

Улучшение КПМ может быть обеспечено, путем непрерывного отслеживания и адаптации к современным ПП рынка. Повышая КГУ, м-г будут напрямую способствовать повышению качества РГ. Нынешний декларативный уровень качества должен поддерживаться на высочайшем уровне для того, чтобы:

- улучшить КГУ, чтобы гости получили наибольшую ценность;

- обеспечить конкурентоспособность на рынке лучших гостиниц для создания высоких стандартов качества;

- интегрировать размещение в системе качества.

Проведенные авторами данной статьи исследования, определили много вопросов и это только маленький шаг в сторону того, что предлагается, и, как таковые, представляют основу для будущих исследований. Т. о., можно подчеркнуть необходимость более интенсивных исследований КГУ м-г, а также УП в качестве единственного истинного измерения качества.

Стандарты м-г играют важную роль в достижении КГУ. Они должны определить (т. е. предписать) КГУ, а также представлять собой меру для достижения предписанного качества. Результаты исследования показывают, что КГУ, бесспорно, находится под влиянием КГ. Рейтинг качества (и цены) содержится в КГ и обозначается числом звезд. Самые высокие категории $(5 *)$ имеют самые высокие стандарты и обеспечивают наилучшее КГУ и ГП, предоставляют широчайший выбор удобств по самым высоким ценам. В этом смысле, ММ должны следить за постоянным совершенствованием КГУ.

Кроме того, исследования показали, что ММ признал важность повышения категории гостиницы, свидетельствующий о значении высшей категории среднестатистической м-Г по сравнению с др. ГУ. Это требует постоянного целенаправленного инвестирования в улучшение ГП и ГУ в смысле управленческих навыков, для постоянного развития системы, гарантирующей, например, интеграцию с ПП в наилучших стандартах и показателях.

Т. о., эта статья имеет дело с ТК м-г, что ссылается на категорию м-г (т.е., ощутимый аспект обслуживания) и, в то же время, заботится о ФК, которое включает в себя порядок предоставления ГУ как неосязаемый аспект обслуживания (отношение к гостям, атмосфера в отеле, внешность персонала).

\section{8. Выводы}

Украина постепенно завоевывает свои позиции на мировом тур. РГ. В настоящее время развитие тур. сферы в стране должно идти в направлении поиска средств преодоления кризисных явлений и интенсификации производства качественного тур. продукта. В условиях резкой переориентации тур. потоков особое внимание следует уделять созданию эффективных организационно-управленческих структур, регулированию механизмов стимулирования РГ, разработке эф- фективной стратегии развития туризма, как на региональном, так и на нац. уровнях, эк. свободе производителей ГП. Это обеспечит РГ качественными ГУ и будет способствовать социально-экономическому развитию страны.

Исследование сосредоточено на повышении КГУ, связанном с увеличением объекта гостиничного хозяйства на 1 категорию (например, звезду). В самом деле, как качество представляет "совокупность ГП или ГУ характеристик, определяющих их возможности или их использование", возможные ограничения отражены в важности качества, что появляется в требованиях клиентов (например, ПП, пожеланиях и ожиданиях). Это представление относится к УП, которые иногда не связанны с категорией объекта, в котором они остановились, хотя и связаны с рядом других элементов. Гости будут оценивать КГУ по оценке из нескольких элементов (например, измерение ГУ, таких как доброта персонала, качество еды и питья, размер, внешний вид и комфорт номеров, чистота, последовательность предоставления услуг, местоположение, вид отеля, универсальность выбора, безопасность, стоимость номеров). Поэтому некоторые авторы считают, что уже не достаточно просто выполнить запросы гостей, но, обязательно надо радовать, а еще лучше восхищать и приятно удивлять клиентов.

Если качество подразумевает выполнение запросов клиентов, с целью внедрения и поддержания конкурентного качества важно, чтобы постоянно озвучивались запросы гостей, с одной стороны, и, чтобы было наличие умения ММ выполнить эти запросы, с др. стороны. Так, можно было бы обеспечить реализацию непрерывных улучшений, в соответствии с запросами гостей.

Следовательно, дальнейшие исследования КГУ, с учетом ожиданий и их восприятия того, чтобы избежать возможных расхождений между реальными ожиданиями гостей и восприятием ММ ожиданий гостей.

\section{Благодарности}

Авторы этой статьи выражают благодарности ММ и персоналу 70 мини-гостиниц, любезно согласившихся принять участие в анкетировании, организованном авторами.

\section{Литература}

1. Положення про малі готелі, мотелі, пансіонати. Затверджено постановою Верховної Ради АР Крим від 19.03.2003 p. No 487-3/03 (зі змінами та доповненнями) [Электронный pecypc] / Режим доступа: www.tourism.crimea.ua

2. ДСТУ 4268:2003. Державний стандарт України. Послуги туристичні. Засоби розміщення. Загальні вимоги. Видання офіційне. Розроблено Держтурадміністрацією спільно $з$ ДП НДІ «Система», м. Львів. Введено в дію 3 01.07.2004 р. [Текст] / К.: Держспоживстандарт України, 2004. - 14 с. - Режим доступу: http://www.dnaop.com/html/ 29982/doc-ДСТУ_4269_2003

3. Мусакин, А. Мини-отели это не просто маленькие гостиницы [Текст] / А. Мусакин // Гостинничный \& Ресторанный бизнес. -2007 . - № 1. - С. 56-57.

4. Журнал "Гостиничный и ресторанный бизнес" [Электронный ресурс] / Режим доступа: http://www.hotelbiz.com.ua/ 
5. Мишин, В. Управление качеством: Учебник для студентов вузов, обучающихся по специальности «Менеджмент организации» [Текст] / В. Мишин; 2-е изд. перераб. и доп. - М.: ЮНИТИ-ДАНА, 2005. -463 с.

6. Котлер, Ф. Маркетинг. Гостеприимство. Туризм: Учебник для студентов вузов [Текст] / Ф. Котлер, Дж. Боуэн, Дж. Мейкенз; пер. с англ.; 4-е изд., перераб. и доп. - М.: ЮНИТИ-ДАНА, 2012. - $1071 \mathrm{c.}$

7. Hall, R. The Strategic Analysis of Intangible Resources [Text] / R. Hall // Strategic Management Journal. - 1992. - Vol. 13, Issue 2. - P. 135-144. doi: 10.1002/smj.4250130205

8. Coyne, K. P. Sustainable Compeitive Advantage - what it is, what it isn't [Text] / K. P. Coyne // Business Horizons. 1986. - Vol. 29, Issue 1. - P. 54-61. doi: /10.1016/00076813(86)90087-x

9. Bull, A. The Economics of Travel and Tourism [Text]/ A. Bull; 2nd ed. - Melbourne: Longman, 1995. - 272 p.

10. Evans, N. Strategic Management for Travel and Tourism [Text] / N. Evans, D. Campbell, G. Stonehouse. Oxford: Butterworth-Heinemann, 2003. -420 p.

11. Porter, M. E. Competitive Strategy: Techniques for Analyzing Industries and Competitors [Text] / M. E. Porter. New York: The Free Press, 1980. - 397 p.

12. Barney, J. B. Gaining and Sustaining Competivie Advantage [Text] / J. B. Barney; 4nd ed. - Upper Saddle River, NJ: Prentice Hall - New York, 2010. -512 p.

13. Porter, M. E. Competitive Advantage - Creating and Sustaining Superior Performance [Text] / M. E. Porter; $1^{\text {st }}$ ed. New York: The Free Press, 1998. - 592 p.

14. Zeithaml, V. A. Consumer Pereceptions of Price, Quality, and Value: A Means-End Model and Synthesis of Evidence [Text] / V. A. Zeithaml // Journal of Marketing. - 1998. Vol. 52, Issue 3. - P. 2-22. doi: 10.2307/1251446

15. Berry, L. L. The Service-Quality Puzzle [Text] / L. L. Berry, A. Parasuraman, V. A. Zeithaml // Business Horizons. 1998. - Vol. 41, Issue 15. - P. 35-43. doi: 10.1016/00076813(88)90053-5

16. Bitner, M. J. Encounter satisfaction versus overall satisfaction versus quality [Text] / M. J. Bitner, A. R. Hubbert; R. Rust, R. Oliver (Eds.). - Service quality: New Directions in Theory and Practice. London: Sage Publications, 1994. - P. 72 94. doi: $10.4135 / 9781452229102 . n 3$

17. Stevenson, W. J. Production/Operations Management [Text] / W. J. Stevenson; 4th ed. - Boston: Irwin Homewood, 1993.

18. Schroeder, R. G. Operations Management Contemporary Concepts and Cases [Text] / R. G. Schroeder; $5^{\text {th }}$ Revised Ed. - Boston: McGraw Hill, 2010. - 544 p.

19. Dawes, J. Negative evaluations of service quality - a framework for identification and response [Text] / J. Dawes, J. Rowley // Journal of Marketing Practice: Applied marketing Science. 1999. - Vol. 5, Issue 2. - P. 46-55. doi: 10.1108/ eum0000000004554

20. Brady, M. K. Some New Thoughts on Conceptualizing Perveived Service Quality: A Hierarchical Approach [Text] / M. K. Brady, J. J. Cronin // Journal of Marketing. - 2001. - Vol. 65, Issue 3. - P. 34-49. doi: 10.1509/jmkg.65.3.34.18334

21. Avelini Holjevac, I. Total Quality Management [Text] / I. Avelini Holjevac // Nase gospodarstvo: revija za aktualna gospodarska vprasanja. - 1997. - Vol. 1, Issue 2. - P. 47-55.

22. Cerovic, Z., Pavia, N., Galicic, V. Organizacija i kategorizacija ugostiteljskih objekata [Text] / Z. Cerovic, N. Pavia, V. Galicic. - Opatija: FTHM Opatija, 2005.

23. Pizam, A. Customer satisfaction and its measurement in hospitality enterprises [Text] / A. Pizam, T. Ellis // International Journal of Contemporary Hospitality Management. 1999. - Vol. 11, Issue 7. - P. 326-340. doi: 10.1108/ 09596119910293231
24. Dube, L. Building Customer Loyality [Text] /Dube, L. M. Renaghan // Cornell Hotel and Restaurant Ad- ministration Quarterly. - 1999. - Vol. 40, Issue 5. - P. 86.

25. Ватолкина, Н. Ш. Систематизация подходов к определению категории «качество услуг» [Текст] / Н. Ш. Ватолкина // Вестник Тихоокеанского государственного экономического университета. - 2012. - № 4. - С. 82-93.

26. Beddowes, P. Service Success! Who is Getting There [Text] / P. Beddowes, S. Gulliford, M. Knight, I. Saunders // Operations Management Association, University of Nottingham. 1987. - Vol. 6

27. Ghobadian, A. Service Quality Concepts and Models [Text] / A. Ghobadian, S. Speller, M. Jones // International Journal of Quality \& Reliability Management. - 1994. - Vol. 11, Issue 9. - P. 43-66.

28.Gupta, S. The contextual and dialectical nature of experiences [Text] / S. Gupta, M. Vajic; J. Fitzsimmons, L. Fitzsimmons (Eds.). - New service development, Thousand Oaks: Sage, 2000. - P. 33-51. doi: 10.4135/9781452205564.n2

29. Schneider, B. Service Quality. Research Perspectives [Text] / B. Schneider, S. S. White. - Foundations for Organizational Sciences; Sage Publications, 2004. - 185 p.

30. Onkvisit, S. Consumer Behavior: Strategy and Analysis [Text] / S. Onkvisit, J. J. Shaw. - New York: Macmillan, 1994. $-654 \mathrm{p}$.

31. Sandstrom, S. Technology-based service experiences: A Study of Functional and Emotional Dimensions of Telecom Services [Text] : Licentiate Thesis / S. Sandstrom // Karlstad University Studies. Universitetstryckeriet, Karlstad. - 2008. Vol. 3. - P. 48.

32. Brogowicz, A. A. A synthesised service quality model with managerial implications [Text] / A. A. Brogowicz,

L. M. Delene, D. M. Lyth // International Journal of Service Industry Management. - 1990. - Vol. 1, Issue 1. - P. 27-44. doi: 10.1108/09564239010001640

33. Schneider, B. Service Quality. Research Perspectives [Text] / B. Schneider, S. S. White. - Foundations for Organizational Sciences; Sage Publications, 2004. - 185 p.

34. Surprenant, C. F. Service encounters are human interactions [Text] / C. F. Surprenant, M. R. Solomon,

E. G. Gutman // Journal of Business Research. - 1983. - Vol. 20. - P. 13-21.

35. Czepiel, J. A. Service encounters and service relationships: implications for research [Text] / J. A. Czepiel // Journal of Business Research. - 1990. - Vol. 20, Issue 1. - P. 13 21. doi: 10.1016/0148-2963(90)90038-f

36. Ghobadian, A. Service Quality Concepts and Models [Text] / A. Ghobadian, S. Speller, M. Jones // International Journal of Quality \& Reliability Management. - 1994. - Vol. 11, Issue 9. - P. 43-66. doi: 10.1108/02656719410074297

37. Edvardsson, B. Service Quality Improvement [Text] / B. Edvardsson // Managing Service Quality: An International Journal. - 1998. - Vol. 8, Issue 2. - P. 142-149. doi: 10.1108/09604529810206972

38. Svensson, G. A customized construct of sequential service quality in service encounter chains: time, context, and performance threshold [Text] / G. Svensson, // Managing Service Quality: An International Journal. - 2004. - Vol. 14, Issue 6. - P. 468-475. doi: 10.1108/09604520410569801

39. Svensson, G. A Generic Conceptual Framework of Interactive Service Quality [Text] / G. Svensson // Managing Service Quality: An International Journal. - 2003. - Vol. 13, Issue 4. - P. 267-275. doi: 10.1108/09604520310484680

40. Dabholkar, P. A. A Comprehensive framework for service quality: an investigation of critical conceptual and measurement issues through a longitudinal study [Text] / P. A. Dabholkar, C. D. Shepherd, D. I. Thorpe // Journal of Retailing. - 2000. - Vol. 76, Issue 2. - P. 131-139. doi: $10.1016 / \mathrm{s} 0022-4359(00) 00029-4$ 
41. Хаксевер, К. Управление и организация в сфере услуг [Текст] / К. Хаксевер, Б. Рендер, Р. Рассел, Р. Мердик; под ред. В. Кулибановой; 2-е изд.: пер. с англ. - СПб.: Питер, 2002. - 752 c.

42. Mattsson, J. A service quality model based on ideal value standard [Text] / J. Mattsson // International Journal of Service Industry Management. - 1992. - Vol. 3. Issue 3. - P. 1833. doi: $10.1108 / 09564239210015148$

43. Vargo, S. L. Evolving to a New Dominant Logic for Marketing [Text] / S. L. Vargo, R. F. Lusch // Journal of Marketing. - 2004. - Vol. 68. Issue 1. - P. 1-17. doi: 10.1509/jmkg.68.1.1.24036

44. Gentile, C. How to Sustain the Customer Experience: An Overview of Experience Components that Co-create Value with the Customer [Text] / C. Gentile, N. Spiller, G. Noci // European Management Journal. - 2007. - Vol. 25, Issue 5. - P. 395-410. doi: 10.1016/j.emj.2007.08.005

45. SPSS software [Electronic resource] / Available at: www.spss.com/home_/up107.htm/17.10.2005/

46. Dahtijarevic-Siber, F. Human potential management [Text] / F. Dahtijarevic-Siber. - Zagreb: Golden Marketing Zagreb, 1999.

47. Про порядок надання послуг 3 тимчасового розміщення (проживання). Затверджено постановою КМУ від 15.03.2006 p. № 297 [Електроний ресрус] / Режим доступу: www.tourism.gov.ua

48. Федоров, Р. Г. Гостиничный бизнес как составляющая современной индустрии туризма [Текст] / Р. Г. Федоров // Молодой ученый. - 2013. - № 4. - С. 307-311.

49. Лойко, О. Т. Туризм и гостиничное хозяйство [Текст] : уч. пос. / О. Т. Лойко. - Томск: Изд-во ТПУ, 2007. $157 \mathrm{c}$.

50. ДСТУ 4527:2006. Державний стандарт України. Послуги туристичні. Засоби розміщення. Терміни та визначення. Видання офіційне [Текст] / Розроблено Держтурадміністрацією спільно з ДП НДІ «Система», м. Львів. Введено в дію $з$ 01.10.2006 р. - К.: Держспоживстандарт України, 2006. - 28 с.

51. Байлик, С. Гостиничное хозяйство. Организация, управление, обслуживание [Текст] : уч. пос. / С. Байлик; 2-е изд., перераб. и доп. - К.: Дакор, 2006. - 288 с.

52. Мусакин, А. Малый отель: с чего начать, как преуспеть. Советы владельцам и управляющим [Текст] / А. Мусакин. - СПб.: Питер, 2007. - 320 с.

53. Готелі та інші місця для короткотермінового проживання Одеської області (статистичний збірник) [Текст] / Одеса: Головне управління статистики в Одеській області, 2007. - 73 c.

\section{References}

1. Polozhennya pro mali goteli, moteli, pansionati. Zatverdzheno postanovoyu Verhovnoyi Radi AR Krim vid 19.03.2003. No 487-3/03 (zi zminami ta dopovnennyami). Available at: www.tourism.crimea.ua

2. DSTU 4268:2003. Derzhavniy standart Ukrayini. Poslugi turistichni. Zasobi rozmischennya. Zagalni vimogi. Vidannya ofitsiyne (2004). Rozrobleno Derzhturadministratsieyu spilno z DP NDI «Sistema», m. Lviv. Vvedeno $\mathrm{v}$ diyu $\mathrm{z}$ 01.07.2004. Kiev: Derzhspozhivstandart Ukrayini, 14. Available at: http://www.dnaop.com/html/29982/doc-DSTU 42692003

3. Musakin, A. (2007). Mini-oteli eto ne prosto malenkie gostinitsyi. Gostinnichnyiy \& Restorannyiy biznes, 1, 56-57.

4. Zhurnal "Gostinichnyiy i restorannyiy biznes". Available at: http://www.hotelbiz.com.ua/

5. Mishin, V. (2005). Upravlenie kachestvom: Uchebnik dlya studentov vuzov, obuchayuschihsya po spetsialnosti «Menedzhment organizatsii». Second edition. Moscow: YuNITIDANA, 463 .

6. Kotler, F., Bouen, Dzh., Meykenz, Dzh. (2012). Marketing. Gostepriimstvo. Turizm: Uchebnik dlya studentov vuzov. Fourth edition. Moscow: YuNITI-DANA, 1071.
7. Hall, R. (1992). The Strategic Analysis of Intangible Resources. Strategic Management Journal, 13 (2), 135-144. doi: 10.1002/smj.4250130205

8. Coyne, K. P. (1986). Sustainable Compeitive Advantage - what it is, what it isn't. Business Horizons, 29 (1), 54-61. doi: /10.1016/0007-6813(86)90087-x

9. Bull, A. (1995). The Economics of Travel and Tourism. Second edition. Melbourne: Longman, 272.

10. Evans, N., Campbell, D., Stonehouse, G. (2003). Strategic Management for Travel and Tourism. Oxford: Butterworth-Heinemann, $420 \mathrm{p}$.

11. Porter, M. E. (1980). Competitive Strategy: Techniques for Analyzing Industries and Competitors. New York: The Free Press, 397.

12. Barney, J. B. (2010). Gaining and Sustaining Competivie Advantage. Fourth edition. Upper Saddle River, NJ: Prentice Hall. New York, 512.

13. Porter, M. E. (1998). Competitive Advantage Creating and Sustaining Superior Performance. First edition. New York: The Free Press, 592.

14. Zeithaml, V. A. (1998). Consumer Pereceptions of Price, Quality, and Value: A Means-End Model and Synthesis of Evidence. Journal of Marketing, 52 (3), 2-22. doi: $10.2307 / 1251446$

15. Berry, L. L., Parasuraman, A., Zeithaml, V. A. (1998). The Service-Quality Puzzle. Business Horizons, 41 (15), 35-43. doi: 10.1016/0007-6813(88)90053-5

16. Bitner, M. J., Hubbert, A. R.; Rust, R., Oliver R. (Eds.) (1994). Encounter satisfaction versus overall satisfaction versus quality. Service quality: New Directions in Theory and Practice. London: Sage Publications, 72-94. doi: 10.4135/9781452229102.n3

17. Stevenson, W. J. (1993). Production/Operations Management. Fourth edition. Boston: Irwin Homewood.

18. Schroeder, R. G. (2010). Operations Management Contemporary Concepts and Cases. $5^{\text {th }}$ Revised Ed. Boston: McGraw Hill, 544.

19. Dawes, J., Rowley, J. (1999). Negative evaluations of service quality - a framework for identification and response. Journal of Marketing Practice: Applied marketing Science, 5 (2), 46-55. doi: 10.1108/eum0000000004554

20. Brady, M. K., Cronin, J. J. (2001). Some New Thoughts on Conceptualizing Perveived Service Quality: A Hierarchical Approach. Journal of Marketing, 65 (3), 34-49. doi: 10.1509/jmkg.65.3.34.18334

21. Avelini Holjevac, I. (1997). Total Quality Management. Nase gospodarstvo: revija za aktualna gospodarska vprasanja, 1 (2), 47-55.

22. Cerovic, Z., Pavia, N., Galicic, V. (2005). Organizacija i kategorizacija ugostiteljskih objekata. Opatija: FTHM Opatija.

23. Pizam, A., Ellis, T. (1999). Customer satisfaction and its measurement in hospitality enterprises. International Journal of Contemporary Hospitality Management, 11 (7), 326-340. doi: 10.1108/09596119910293231

24. Dube, L., Renaghan, L. M. (1999). Building Customer Loyality. Cornell Hotel and Restaurant Administration Quarterly, 40 (5), 86.

25. Vatolkina, N. Sh. (2012). Systematization of the approaches to "service quality" definition. Bulletin of the Pacific state Economic University, 4, 82-93

26. Beddowes, P., Gulliford, S., Knight, M., Saunders, I. (1987). Service Success! Who is Getting There. Operations Management Association, University of Nottingham, 6.

27. Ghobadian, A., Speller, S., Jones, M. (1994). Service Quality Concepts and Models. International Journal of Quality \& Reliability Management, 11 (9), 43-66.

28. Gupta, S., Vajic, M.; Fitzsimmons, J., Fitzsim- mons, M. (Eds.) (2000). The contextual and dialectical nature of experiences. New service development, Thousand Oaks: Sage, 33-51. doi: 10.4135/9781452205564.n2 
29. Schneider, B., White, S. S. (2004). Service Quality. Research Perspectives // Foundations for Organizational Sciences; Sage Publications, 185.

30. Onkvisit, S., Shaw, J. J. (1994). Consumer Behavior: Strategy and Analysis. New York: Macmillan, 654.

31. Sandstrom, S. (2008). Technology-based service experiences: A Study of Functional and Emotional Dimensions of Telecom Services. Licentiate Thesis. Karlstad University Studies. Universitetstryckeriet, Karlstad, 3, 48.

32. Brogowicz, A. A., Delene, L. M., Lyth, D. M. (1990). A synthesised service quality model with managerial implications. International Journal of Service Industry Management, 1 (1), 27 44. doi: 10.1108/09564239010001640

33. Schneider, B., White, S. S. (2004). Service Quality. Research Perspectives. Foundations for Organizational Sciences; Sage Publications, 185.

34. Surprenant, C. F., Solomon, M. R., Gutman, E. G. (1983). Service encounters are human interactions. Journal of Business Research, 20, 13-21.

35. Czepiel, J. A. (1990). Service encounters and service relationships: implications for research. Journal of Business Research, 20 (1), 13-21. doi: 10.1016/0148-2963(90)90038-f

36. Ghobadian, A., Speller, S., Jones, M. (1994). Service Quality Concepts and Models. International Journal of Quality \& Reliability Management, 11 (9), 43-66.

doi: 10.1108/02656719410074297

37. Edvardsson, B. (1998). Service Quality Improvement. Managing Service Quality: An International Journal, 8 (2), 142149. doi: $10.1108 / 09604529810206972$

38. Svensson, G. (2004). A customized construct of sequential service quality in service encounter chains: time, context, and performance threshold. Managing Service Quality: An International Journal, 14 (6), 468-475. doi: 10.1108/ 09604520410569801

39. Svensson, G. (2003). A Generic Conceptual Framework of Interactive Service Quality. Managing Service Quality: An International Journal, 13 (4), 267-275. doi: 10.1108/09604520310484680

40. Dabholkar, P. A., Shepherd, C. D., Thorpe, D. I. (2000). A Comprehensive framework for service quality: an investigation of critical conceptual and measurement issues through a longitudinal study. Journal of Retailing, 76 (2), 131139. doi: 10.1016/s0022-4359(00)00029-4

41. Haksever, K., Render, B., Rassel, R., Merdik, R.; Kulibanova, V. (Ed.) (2002). Upravlenie i organizatsiya v sfere uslug. Second edition. SPb.: Piter, 752.

42. Mattsson, J. (1992). A service quality model based on ideal value standard. International Journal of Service Industry Management, 3 (3), 18-33. doi: 10.1108/09564239210015148

43. Vargo, S. L., Lusch, R. F. (2004). Evolving to a New Dominant Logic for Marketing. Journal of Marketing, 68 (1), 117. doi: $10.1509 / \mathrm{jmkg} \cdot 68.1 .1 .24036$

44. Gentile, C., Spiller, N., Noci, G. (2007). How to Sustain the Customer Experience: An Overview of Experience Components that Co-create Value with the Customer. European Management Journal, 25 (5), 395-410.

doi: $10.1016 /$ j.emj.2007.08.005

45. SPSS software. Available at: www.spss.com/home /up107.htm/17.10.2005/

46. Dahtijarevic-Siber, F. (1999). Human potential management. Zagreb: Golden Marketing Zagreb.

47. Pro poryadok nadannya poslug $\mathrm{z}$ timchasovogo rozmIschennya (prozhivannya). Zatverdzheno postanovoyu KMU vId 15.03.2006 r. No 297. Available at: www.tourism.gov.ua

48. Fedorov, R. G. (2013). Gostinichnyiy biznes kak sostavlyayuschaya sovremennoy industrii turizma. Molodoy uchenyiy, 4, 307-311.

49. Loyko, O. T. (2007). Turizm i gostinichnoe hozyaystvo: Uchebnoe posobie. Tomsk: Izd-vo TPU, 157.

50. DSTU 4527:2006. Derzhavniy standart UkraYini. Poslugi turistichnI. Zasobi rozmIschennya. TermIni ta viznachennya. Vidannya ofItsIyne. Rozrobleno DerzhturadmInIstratsIEyu spIlno z DP NDI «Sistema», LvIv (2006). Vvedeno v dIyu z 01.10.2006. Kiev: Derzhspozhivstandart UkraYini, 28.

51. Baylik, S. (2006). Gostinichnoe hozyaystvo. Organizatsiya, upravlenie, obsluzhivanie. Ucheb. Posobie. Second edition. Kiev: Dakor, 288.

52. Musakin, A. (2007). Malyiy otel: s chego nachat, kak preuspet. Sovetyi vladeltsam i upravlyayuschim. SPb.: Piter, 320.

53. GotelI ta InshI mIstsya dlya korotkotermInovogo prozhivannya OdeskoYi oblastI (statistichniy zbIrnik) (2007). Odesa: Golovne upravlInnya statistiki v OdeskIy oblastI, 73.

Дата надходження рукопису 27.12.2014

Левыкин Виктор Макарович, доктор технических наук, профессор, заведующий кафедрой, кафедра информационных управляющих систем, Харьковский национальный институт радиоэлектроники, пр. Ленина, 16, г. Харьков, Украина, 61166

E-mail: iyc@kture.kharkov.ua

Дэвон Валерия Викторовна, кафедра информационных управляющих систем, Харьковский национальный институт радиоэлектроники, пр. Ленина, 16, г. Харьков, Украина, 61166

E-mail: iyc@kture.kharkov.ua

\section{УДК 661.811}

DOI: $10.15587 / 2313-8416.2015 .36155$

\section{УДАЛЕНИЕ ВОДЫ ИЗ СЛАБОПОЛЯРНЫХ ЖИДКОСТЕЙ ТВЁРДЫМИ АДСОРБЕНТАМИ}

\section{()А. Н. Бутенко, И. М. Рышенко, Н. А. Блинков}

Применение альтернативных оксигенатных топлив вместо бензинового топлива может дать цельй ряд преимуществ для двигателя, однако этому препятствует также ряд недостатков. Разрабатываются методы, задачей которым ставится устранение вышеуказанных недостатков. Известно, что оксигенатные топлива являются продуктами гидролиза растительных производств, и поэтому их можно применять как альтернативное топливо. Рассматриваются особенности обезвоживания низкополярных жидкостей Ключевые слова: топливо, этанол, гидролиз, температура, обезвоживание, двигатель, теплота сгорания, органические жидкости, расслаивание, бензин 